\title{
SOM and Biomass C Stocks in Degraded and Undisturbed Andean and Coastal Nothofagus Forests of Southwestern South America
}

\author{
Francis Dube ${ }^{1, *}$ and Neal B. Stolpe ${ }^{2}$ \\ 1 Department of Silviculture, Faculty of Forest Sciences, University of Concepción, Victoria 631, Casilla 160-C, \\ Concepción 4030000, Chile \\ 2 Soils and Natural Resources Department, Faculty of Agronomy, University of Concepción, \\ Vicente Méndez 595, Casilla 537, Chillan 3812120, Chile; nstolpe@udec.cl \\ * Correspondence: fdube@udec.cl; Tel.: +56-41-220-4982
}

Academic Editors: Philip J. Polglase and Mark E. Harmon

Received: 31 August 2016; Accepted: 2 December 2016; Published: 20 December 2016

\begin{abstract}
Grazing and over-exploitation can severely degrade soil in native forests. Considering that productivity in ecosystems is related to soil organic matter (SOM) content and quality, the objectives of this study were to: (1) determine the influence of degraded (DEF), partly-degraded (PDF), and undisturbed (UNF) Nothofagus forests on the stocks of carbon (C) in tree biomass and SOM; (2) evaluate fractions of SOM as indicators of sustainable management; and (3) use the Century model to determine the potential gains of soil organic C (SOC). The forests are located in the Andes and Coastal mountains of southern Chile. The SOM was fractionated to separate the light fraction (LF), macroaggregates $(>212 \mu \mathrm{m})$, mesoaggregates $(212-53 \mu \mathrm{m})$, and microaggregates $(<53 \mu \mathrm{m})$. In two measurement periods, the SOC stocks at $0-20 \mathrm{~cm}$ and $20-40 \mathrm{~cm}$ depths in macroaggregates were on average $100 \%$ higher in the Andean UNF, and SOC was over twice as much at $20-40 \mathrm{~cm}$ depth in Andean DEF. Century simulations showed that improved silvopastoral management would gradually increase total SOC in degraded soils of both sites, especially the Ultisol with a $15 \%$ increase between 2016 and 2216 (vs. 7\% in the Andisol). Greater SOC in macroaggregates $(p<0.05)$ of UNF indicate a condition of higher sustainability and better management over the years.
\end{abstract}

Keywords: Andisol; century model; Nothofagus obliqua; soil degradation; SOC; Ultisol

\section{Introduction}

Changes in land-uses can modify soil $\mathrm{C}$ stocks through changes in the amount and quality of organic residue that are periodically returned to soil, and also through their subsequent use by soil macro and microorganisms, which affects the net rate of accumulation of organic matter in soil [1]. Increasing the organic matter content of the soil (SOM) improves the overall quality of the soil by improving cation exchange capacity (CEC), aggregate stability, water retention, and biological activity. Increases in SOM levels also favor increased levels of plant growth that also protects the soil from erosion and increases the potential organic residues that are returned to the soil. The SOM can be fractionated in the laboratory according to its "lability" (i.e., the relative ease which it is decomposed by soil microorganisms, thereby releasing nitrogen $(\mathrm{N})$ and other elements that can be used subsequently for plant growth) [2]. The more labile fraction has been used as an indicator of sustainable management because its content in the soil changes in the short term (several months to several years) depending on the vegetation, management, and balance between additions of plant residues and their decomposition in soil [3].

Soil organic matter is rightly considered a key indicator of soil and ecosystem quality because it is sensitive to changes in external management factors, and because its content and quality in the soil 
are related to other soil properties [4]. The SOM content is an "inherent" indicator in the sense that it is influenced by "stable" soil properties, including drainage and clay content. It is also a "dynamic" indicator because its content and quality in soil may change in the short term according to land use and management. Other specific indicators related to the SOM include the total contents of $\mathrm{C}$ and $\mathrm{N}$ in soil and in the light fraction (LF) of organic matter, $\mathrm{C}$ and $\mathrm{N}$ in microbial biomass, microbial respiration rate [4], and the ratio of LF carbon between $0-20 \mathrm{~cm}$ and $20-40 \mathrm{~cm}$ soil depths [3].

Computer modeling can be useful for assessing the long-term effects of management on the soil environment and agroecosystems. The Century model was specifically developed to simulate the dynamics of $C, N$, phosphorus (P), and sulfur (S) through plant litter and soil (0 to $20 \mathrm{~cm}$ depth) in grasslands, crops, forests, and savannas. The model structure includes the active, slow, and passive pools of soil organic matter that have theoretical turnover rates of several months to years, 20 to 50 years, and 400 to 2000 years, respectively. The main input variables are: mean monthly precipitation and air temperature; $\mathrm{N}$ additions from symbiotic fixation and atmospheric deposition; contents of $\mathrm{N}$, $\mathrm{P}, \mathrm{S}$, and lignin of plants; soil texture and $\mathrm{pH}$. Century was used to successfully model the levels of organic $\mathrm{C}$ in soils across the Great Plains of the United States as affected by the main input variables as well as grazing intensity [5]. Simulations are generally most successful for grass and crop systems, and less so for forest ecosystems that have well-developed surface litter overlying the mineral soil [6]. The model has been calibrated to a wide range of soils and vegetation in central Chile [3,7].

In Chile, the multiple land uses, in many cases, are not in equilibrium with the limited potential of these forest ecosystems. According to a recent study in the Biobío Region, $50 \%$ of the Nothofagus secondary forests have such low stocking densities that there should be no intervention at all for the next 10 to 15 years in order to recover normal tree stocking levels. Additionally, $13 \%$ of these forests have reached such a low tree density that they have no chance whatsoever to recover until forest maturity [8]. The underlying cause is that the volumes of extracted timber are higher than what can be restored from natural forest growth, and also because of the presence of cattle that stagnates the natural regeneration processes and causes soil compaction by trampling [9]. In other cases, a rudimentary "coppice" type silvicultural system is being practiced whereby one to several hectares of second-growth forests is clear-cut every 15 years [10]. While this practice permits the use of stems and branches for firewood and charcoal, there is a net export of nutrients from the soil, which, in the long term, destroys the capacity of the forest to regenerate on its own. Currently, there is no governmental regulation regarding the use of second-growth forests for pasturing animals, so the degradation of forest and soils is becoming progressively worse over time [9]. The deforested areas with steeper slopes suffer extreme erosive processes, which further complicate regrowth of the forest [11]. Forest degradation due to deforestation, grazing, and erosion imply that the vegetation removed from the forest will no longer fix atmospheric carbon (C), while the damaged trees that remain and the underlying degraded soils will sequester less $C$ than before, resulting in a net increase in total $C$ emissions to the atmosphere [1].

The objectives of this investigation were to: (1) determine the influence of degraded (DEF), partly-degraded (PDF), and undisturbed (UNF) Nothofagus forest conditions of south central Chile on the quality and distribution of SOM and on the stock of SOC; (2) evaluate fractions of SOM as indicators of sustainable management; and (3) model the sites using Century in order to determine the potential long-term gains of $C$ in the soils as affected by more sustainable management.

\section{Materials and Methods}

\subsection{Site Description}

The Biobío and Araucanía Regions of Chile are the second and fifth largest, respectively, in terms of population and economic productivity, after the Metropolitan Region of Santiago [12]. They extend from the Andes to the Pacific Ocean and cover a total area of 37,063 and 31,842 $\mathrm{km}^{2}$, following the same previous order. Over time, the area of native forest in the regions has diminished as a result of logging and agricultural activities, yet still there remains about 450,000 and 405,000 ha in the Biobío and 
Araucanía Regions, respectively, which are dominated by second-growth "Roble" (Nothofagus obliqua), with patches of "Raulí" (N. nervosa) [8]. Geographically, the second-growth forests are distributed in two broad bands, one along the Andes at altitudes between 600 and 900 meters above sea level, and the other along the Coastal mountain range between 400 and 800 meters above sea level. The latter band, however, is discontinuous because in the Coastal mountain range large areas of native forest have been progressively replaced by the introduction of faster growing plantations (e.g., Pinus radiata). Most of the remaining spots belong to small landowners who use their forests not only as a source of fuel wood and building material but also as areas for cattle grazing and shelter for the animals in winter [8].

The field investigation began in January 2013 in the areas of Los Pellines in the Andean Foothills (Biobío Region), and Chanleo in the Nahuelbuta Coastal Mountain Range (Araucanía Region) of south central Chile (Figure 1). The Andean site is located $45 \mathrm{~km}$ east of the city of Chillan, at altitudes ranging from 650 to $750 \mathrm{~m}$ above sea level at Lat. $36^{\circ} 48^{\prime} \mathrm{S}$, Long. $71^{\circ} 38^{\prime} \mathrm{W}$, while the Coastal site is located $30 \mathrm{~km}$ west of Angol, at 800-900 m elevation and Lat. $37^{\circ} 46^{\prime} \mathrm{S}$, Long. $72^{\circ} 58^{\prime} \mathrm{W}$.
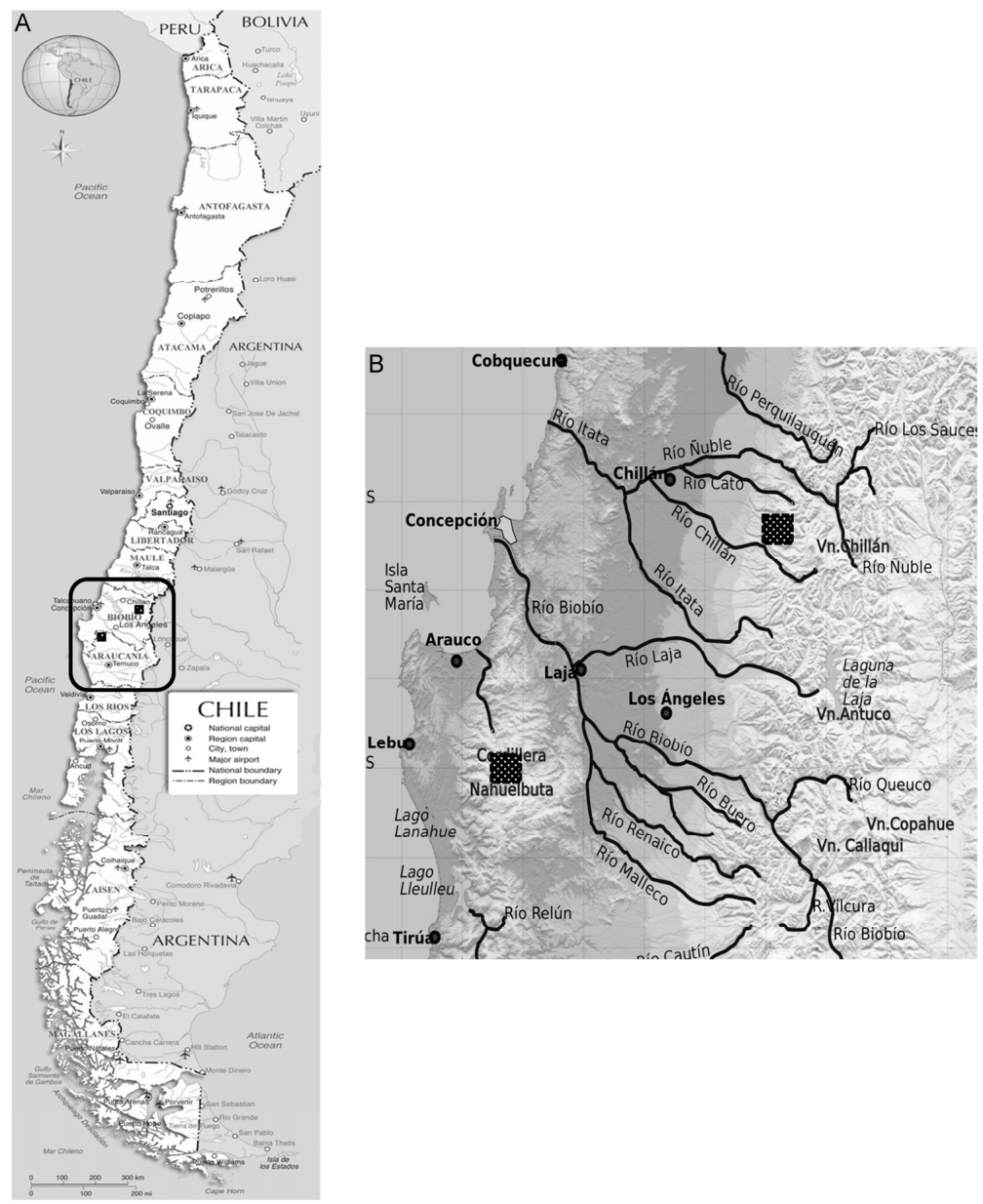

Figure 1. Map of Chile (A) and location of the Biobío and Araucanía Regions (insert); (B) location of Los Pellines and Chanleo Sectors (upper and lower white-dotted squares, respectively) [13].

The climate in the Andean Foothills is classified as warm temperate Mediterranean with short dry seasons ( $<4$ months), with average annual rainfall of $3000 \mathrm{~mm}$ and mean annual temperature of $13.5^{\circ} \mathrm{C}$, whereas in the Coastal Mountains, it is rainy temperate with Mediterranean climatic influence, with average annual precipitation and temperature of $1373 \mathrm{~mm}$ and $13.3{ }^{\circ} \mathrm{C}$, respectively [6,14]. The principal soils in the study areas were volcanic Andisols (medial, amorphic, mesic Typic 
Hapludands) in the Andean Mountains and non-volcanic Ultisols (very fine, mixed, semiactive, mesic Typic Paleudults) in the Coastal Mountains of south central Chile [15-17].

\subsection{Sampling Strategy and Site Classification According to Degradation Status}

In order to preselect the sites for the investigation, an aerial reconnaissance was first performed over the potential study areas in the Andes and Coastal Mountains using a Cessna aircraft equipped with a GPS (Global Positioning System). The aerial survey was carried out in autumn 2012 in order to differentiate the most likely Nothofagus species by the color of their leaves. Accordingly, and following the methodology previously proposed [18] to classify degraded forests, and also considering the available resources and logistical limitations, the study was restricted to three levels of degradation: (i) degraded (DEF); (ii) partly-degraded (PDF); and (iii) undisturbed (UNF) forests. The primary criteria for identification of the level of degradation, as seen from the air, were independent metrics such as the extent of the overall tree coverage, degree of openness of the canopy, and visual indicators of incipient erosion. GPS points (Garmin; Lenexa, KS, USA) were subsequently recorded from the plane over areas of every forest condition at both locations. Later, the ground research crew accessed the aerially measured waypoints with 4-wheel-drive vehicles and extended walks.

In the field, at both geographic locations, for every forest degradation class that was aerially located with GPS, we followed three parallel transects (250-500 m length, $50 \mathrm{~m}$ spacing, with a total of nine per site) with an East-West orientation (Figure 2) in order to ascertain the changes in stand density and degrees of erosion that were initially observed from the air, and to assess any important variations in the actual number of tree species. The vegetation was characteristically Nothofagus obliqua Mirb. (Oerst), with or without the presence of N. nervosa P. et E. (Oerst.) as influenced by the slope aspect. Baseline information about the study areas is provided in Table 1. Depending on the level of degradation and location, accompanying tree species included Aristotelia chilensis (Mol.) Stuntz, Citronella mucronata (Ruiz et Pav.) D. Don, Cryptocarya alba (Mol.) Looser, Drimys winterii J.R. et G. Forster Gevuina avellana Mol., Laurelia sempervirens (Ruiz et Pav.) Tul., Lomatia hirsuta (Lam.) Diels ex Macbr., L. dentata (Ruiz et Pav.) R. Br., Luma apiculata (DC.) Burret, Nothofagus dombeyi Mirb. (Oerst), Persea lingue (Ruiz et Pav.) Nees, and Podocarpus saligna D. Don. In the Andes, the number of tree species varied from 1-5 and 6-8 in DEF and PDF, respectively, while it reached 12 species in UNF; whereas in the Coastal forest, the number of species ranged between one to three and four to six in DEF and PDF, respectively, and reached 14 species in UNF. Additionally, in the more degraded forest, the larger the area of bare soil that is exposed to rain and wind erosion has resulted in the formation of small gullies, especially in the Coastal mountains.
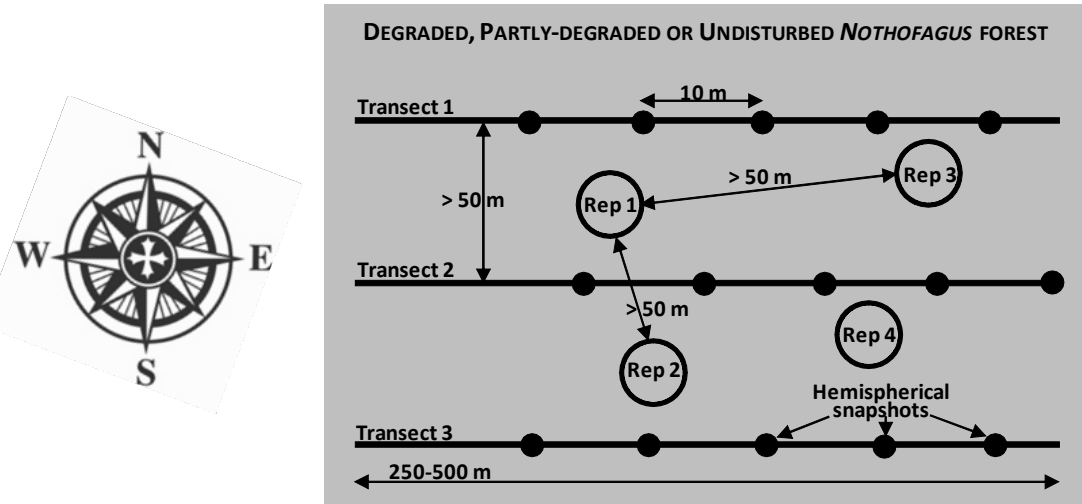

Figure 2. General layout of the treatments (DEF: Degraded, PDF: partly-degraded, UNF: undisturbed Nothofagus forests), sampling design and experimental $500-\mathrm{m}^{2}$ plots (four replicates) established within every set of three parallel transects in the Andean and Coastal mountains of south central Chile. 
Table 1. Baseline information about the two study sites in the Andean and Coastal mountains of south central Chile: Condition (DEF: Degraded, PDF: partly-degraded, UNF: undisturbed forests), principal and accompanying species, and stand density (stems $\left.\cdot \mathrm{ha}^{-1}\right)$, range of diameters $(\mathrm{cm})$, mean diameter at breast height-DBH $(\mathrm{cm})$, basal area $\left(\mathrm{m}^{2} \cdot \mathrm{ha}^{-1}\right)$, and mean total height-HT (m) of Nothofagus obliqua trees.

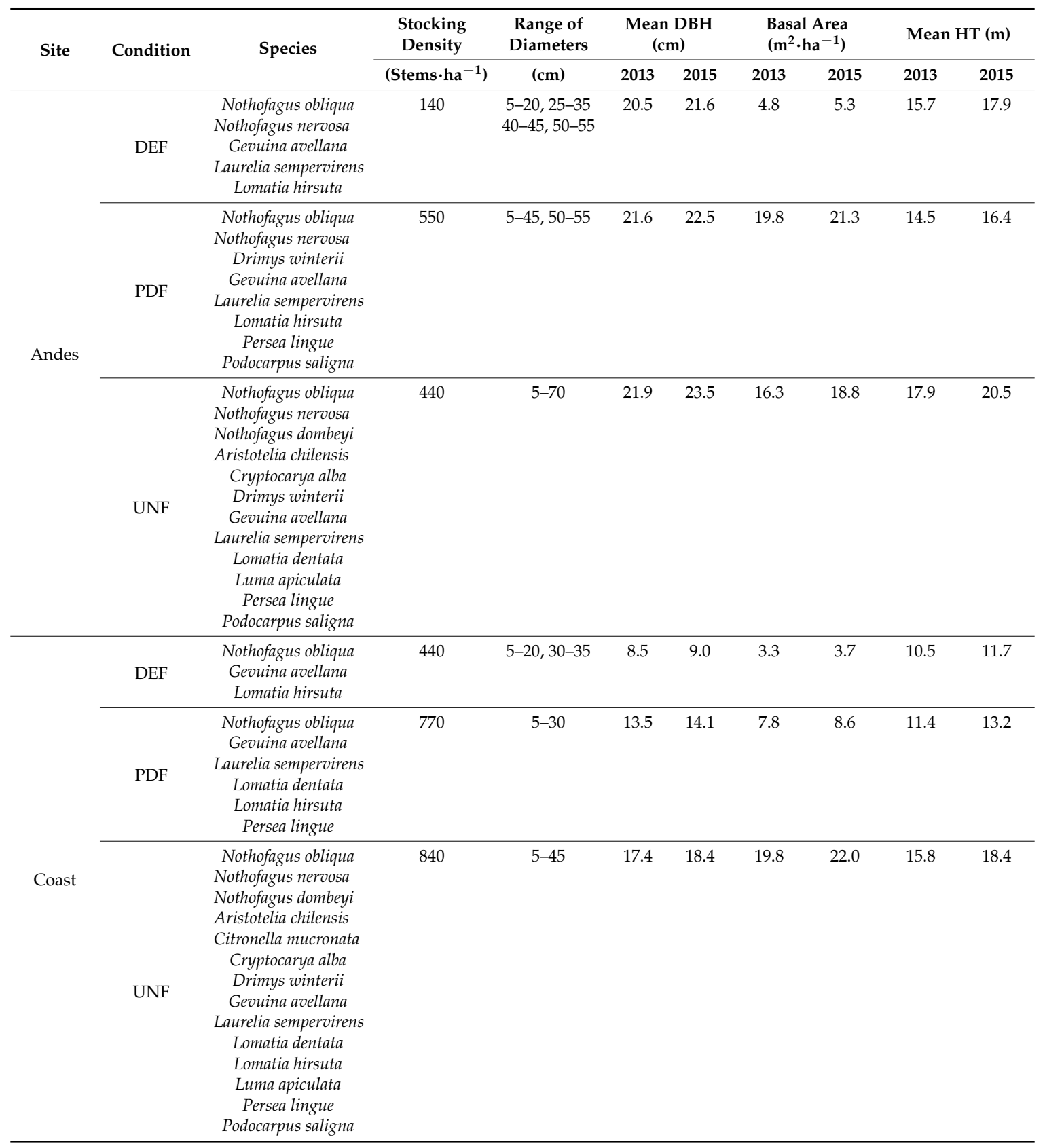

Similarly, over the previously described transects, the degree of openness and leaf area index (LAI) of the forest canopy were measured every $10 \mathrm{~m}$ (Figure 2 ) for each degradation level $(n=75$ hemispherical snapshots per degradation class and 225 snapshots per location) using a Solariscope SOL 300 (Behling, Germany) that was placed at $1.5 \mathrm{~m}$ height above the ground [19]. The Solariscope is an innovative instrument that takes hemispherical photographs and subsequently analyzes them for distinct parameters of interest to the user (e.g., direct and indirect sunlight, tree canopy openness).

The degree of openness of the forest canopy was 50\% $\pm 11 \%, 31 \% \pm 3 \%$, and $8 \% \pm 2 \%$ in the Andean DEF, PDF, and UNF, respectively, and 71\% $\pm 13 \%, 48 \% \pm 9 \%$, and $15 \% \pm 2 \%$ in the Coastal forests following the same order of degradation, with all the differences within each location being 
significant (Student's $t$ test, ${ }^{*} p<0.05$ ). On the other hand, LAI was $1.0 \pm 0.3,1.5 \pm 0.1$, and $3.2 \pm 0.4$ in Andean DEF, PDF, and UNF, respectively, and $0.7 \pm 0.2,1.0 \pm 0.1$, and $2.5 \pm 0.3$ in Coastal forests for the respective treatments. Again, for each location all the differences were found to be significant (Student's $t$ test, ${ }^{*} p<0.05$ ).

The data presented in the previous paragraph were used to test the hypothesis that openness and LAI vary substantially among degradation classes. The marked contrasts within these variables permitted a satisfactory verification of the sites according to their distinct degradation status, as was initially observed from the air. Furthermore, in order to corroborate that the land uses were originally similar to each other (i.e., no logging, agriculture, or pastoral use), so that any current differences can be attributable to anthropogenic degradation, we compared historical aerial photographs of both locations (scale 1:50,000) taken in 1961 by ODEPA (Chilean Office of Agricultural Studies and Policies). This was the earliest year aerial photos were available for the region. The photographs clearly showed and confirmed that continuous, non-fragmented, and non-degraded indigenous forests originally covered the entire study areas of both locations.

Four replicate geo-referenced $500-\mathrm{m}^{2}$ plots were established within every set of three parallel transects (Figure 2) in each of the three forest degradation classes (Degraded (DEF), Partly Degraded (PDF), and Undisturbed (UNF)) (>300 m between classes) at each of the two study sites (Andes and Coast), for 24 plots overall. Each plot was fenced with barbed wire and chicken wire to exclude animals. The plots were selected and established according to forest degradation conditions, but otherwise had similar slopes, uniform exposure, and were located the farthest possible from each other $(>50 \mathrm{~m})$. The experimental design was completely randomized. At each site, mean contrasting of independent populations was performed, hereafter referred to as treatments.

\subsection{Forest Biomass and Determination of $C$ Stock}

An inventory of the Nothofagus obliqua forests was performed in May 2013, 2014, and 2015, using the same circular plots that were previously described. In each plot, we measured the variables DBH (diameter at breast height) and HT (total tree height) of all the Nothofagus obliqua trees (Table 1) using calipers (Haglöf, Långsele, Sweden) and a hypsometer (Suunto, Vantaa, Finland), respectively. Since destructive sampling could not be carried out to determine the aboveground tree biomass, we used a previously established allometric equation that relates aboveground biomass to tree DBH and HT. The biomass function was specifically developed for Nothofagus obliqua forests growing in south central Chile [20] and has the following relationship:

$$
\text { Aboveground biomass }=-262,958+e^{(4.94459+0.0335723 \times \mathrm{DBH}+0.0280054 \times \mathrm{HT})}
$$

where $e$ is the base of the natural logarithm. In order to calculate the $C$ stock of the aboveground tree biomass, we assumed that $50 \%$ of the biomass consists of carbon [21].

\subsection{Soil Analysis}

Soil samples of the $0-5,5-20$, and $20-40 \mathrm{~cm}$ depths were taken from four locations selected at random in September 2013 and 2015, in each of the circular inventory plots. A spade was used to collect samples for chemical analysis and aggregate size fractionation, and another set of samples was taken from the same depths using a cylinder $\left(5.0 \mathrm{~cm}\right.$ diameter, $5.0 \mathrm{~cm}$ height, $\left.98.2 \mathrm{~cm}^{3}\right)$ for determination of bulk density. The chemical analyses were used to determine the mean stock of $\mathrm{C}\left(\mathrm{g} \cdot \mathrm{m}^{-2}\right)$ and $\mathrm{C} / \mathrm{N}$ ratio of the organic matter fractions for each soil depth. The bulk density, soil depth, and respective $\mathrm{C}$ concentration were then used to calculate the weighted average for the soil $\mathrm{C}$ stock in the upper $0-40 \mathrm{~cm}[1,22]$. 


\subsection{Physical Fractionation of Soil Organic Matter}

The SOM fractionation analysis was performed for each sample in the upper $40 \mathrm{~cm}$ of soil from each treatment following the method described by other investigators [23]. The light, intermediate, and heavy fractions of SOM were separated as follows: The soil was mechanically dispersed in a plastic bottle $(250 \mathrm{~mL})$ containing 10 glass beads $(6 \mathrm{~mm}$ diameter $)$ and $180 \mathrm{~mL}$ of distilled water, and shaken at 50 cycles min $^{-1}$ for $16 \mathrm{~h}$. The disrupted soil aggregates were then wet sieved using stainless steel sieves having 212 and $53 \mu \mathrm{m}$ apertures. The light fraction of organic matter and sand (that were retained on the $212 \mu \mathrm{m}$ sieve) were separated by flotation and sedimentation in distilled water [24]. Soil samples were sieved according to separate the following fractions: macroaggregates $(>212 \mu \mathrm{m})$, mesoaggregates $(212-53 \mu \mathrm{m})$, and microaggregates $(<53 \mu \mathrm{m})[25,26]$. The fractions were dried at $50{ }^{\circ} \mathrm{C}$ for $48 \mathrm{~h}$ and weighed. The $\mathrm{C}$ and $\mathrm{N}$ contents of the light, intermediate, and heavy fractions were then measured by dry combustion [27].

\subsection{Century Model Calibration}

Soil parameters were input as required to the Century model (version 4.6) $[5,28]$ and included bulk density, $\mathrm{pH}$, soil texture (0-20 cm depth), and the soil water contents at 33 and $1500 \mathrm{kPa}(0-15$, 15-30, 30-45, 45-60, 60-90, and 90-120 cm depths). The model was calibrated to local climatic conditions using weather data that included monthly means of precipitation, and maximum and minimum temperatures [29], and atmospheric $\mathrm{N}$ deposition was estimated at $2.5 \mathrm{~kg} \cdot \mathrm{ha}^{-1} \cdot \mathrm{year}^{-1}$ [30]. The default values from the model database (for a temperate deciduous forest ecosystem) were used for vegetation variables, but the PRDX (parameter for potential aboveground monthly biomass production for crops) and SITPOT (parameter that relates the soil $\mathrm{N}$ fraction to $\mathrm{N}$ availability, and a higher value gives more $\mathrm{N}$ to grass and less to trees) tree parameters were set to 0.8 and 2.5 , respectively [28,31]. Natural conditions (no grazing) were designated within the model for the years 1 to 1800, which was set in order for stabilization of the site parameters under natural conditions. Afterward (1801 to 2016), typical management systems for degraded forests were input that scheduled heavy grazing of grass pastures among trees for three months of each year, and soil erosion of $1 \mathrm{~kg} \cdot \mathrm{m}^{-2}$ once every five years when there was wood removal. Less intensive management was input for all sites from 2016 to 2216 that included light grazing on grass-legume pastures among trees for three months each year, and soil erosion of $0.01 \mathrm{~kg} \cdot \mathrm{m}^{-2}$ once every five years when there was wood removal (improved silvopastoralism). After input of soil, climatic, and management parameters, the Century model simulations were run for periods representing 2216 years.

\subsection{Statistical Analysis}

The General Lineal Model procedure of SAS v.9.0 [32] for completely randomized designs was used to test the effect of treatments on soil bulk density, soil fractions, and C contents at different depths. Statistical significance $(p<0.01$ and 0.05$)$ between treatments was tested using Student's $t$ test and significant differences within treatments at different depths were tested using Tukey's HSD multiple comparison test. With regard to physical fractionation of SOM, Tukey's HSD test was used to check for significant interactions between depths and fractions for every level of degradation within a given site and year.

\section{Results}

\subsection{Stocks in Tree Biomass and Soil}

The $\mathrm{C}$ stocks per hectare in total aboveground tree biomass (trunks, bark, branches, twigs, and leaves) that were calculated from results of the first forest inventory in the Andes mountains were similar in UNF and PDF, which were significantly greater (by a fourfold magnitude) than the DEF, as depicted in Figure 3A. The same trend was found in the Coastal forests, with the exception that all of the differences among forest conditions were significant $(p<0.05)$, with the $C$ stock being almost four 
times larger in PDF than DEF, and the aboveground C stock in UNF was more than 2.5 and 10 times greater than PDF and DEF, respectively. In addition, it is interesting to see that although C stocks in aboveground tree biomass were over twice as large in the Andean DEF and PDF, as compared with Coastal mountain forests under the same conditions, they were $22 \%$ higher in the Coastal UNF than the Andean UNF (60.2 vs. $\left.49.5 \mathrm{Mg} \cdot \mathrm{C} \cdot \mathrm{ha}^{-1}\right)$.
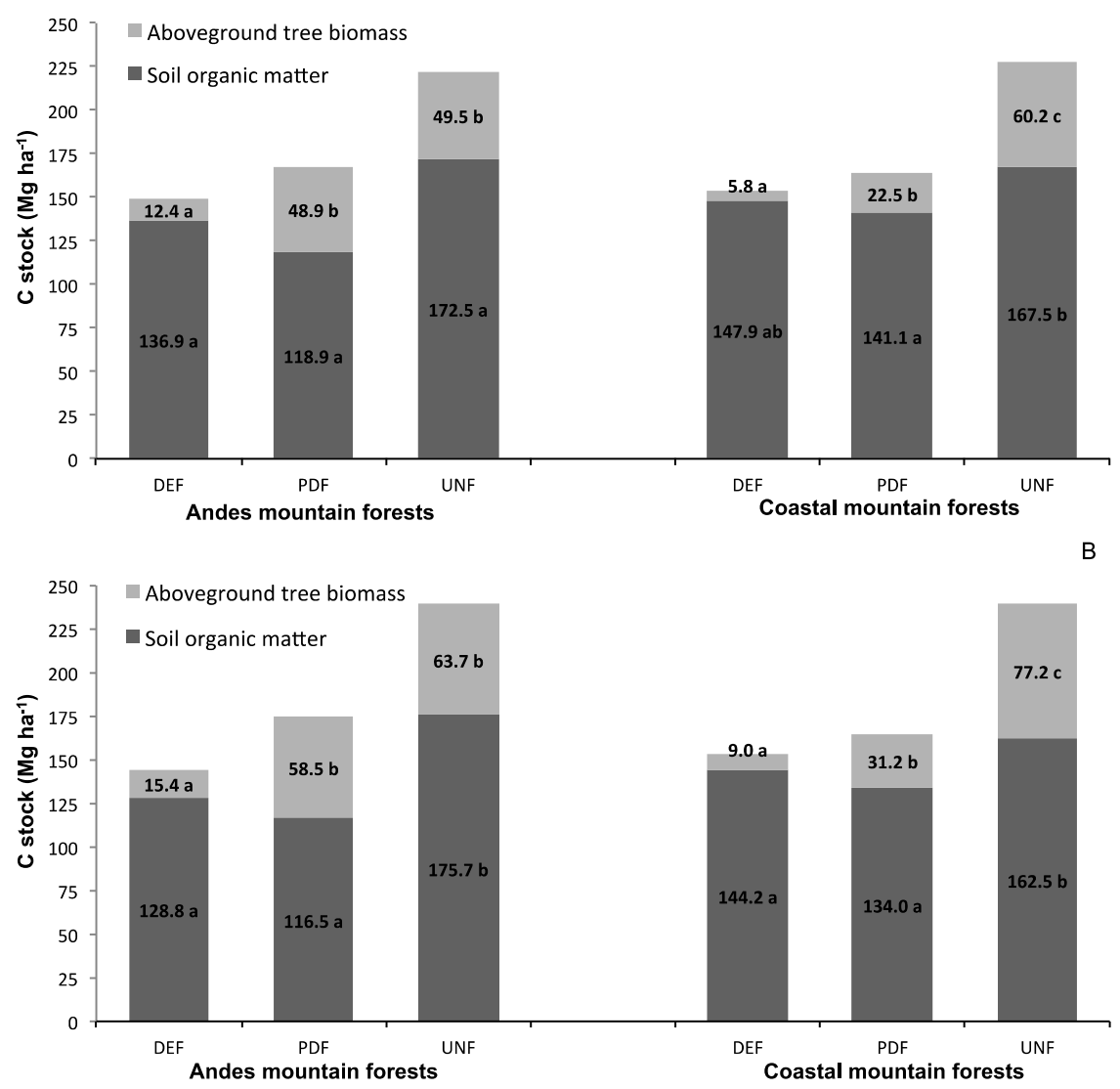

Figure 3. Change in C stocks of aboveground tree biomass and soil organic matter at 0-40 cm depth as influenced by change in Nothofagus forest condition (degraded (DEF), partly-degraded (PDF), and undisturbed (UNF) of the Andean and Coastal mountains of south central Chile in (A) 2013 and (B) 2015. Values with the same lower case letter among forest conditions within a same location and reservoir (tree biomass or SOM) are not significantly different (Student's $t$ test, ${ }^{*} p<0.05$ ). Measurements were taken in September 2013 and 2015.

With respect to soil organic carbon (SOC) stocks, no significant differences were found among Andean forests, although they tended to be highest in the UNF condition. In the Coastal zone, SOC was significantly higher $(p<0.05)$ in UNF than PDF. Total C stocks (ecosystem C stocks) were 222, 168, and $149 \mathrm{Mg} \cdot \mathrm{ha}^{-1}$ in the Andean UNF, PDF, and DEF, respectively, while in the Coastal mountains, they were 228,164 , and $154 \mathrm{Mg} \cdot \mathrm{ha}^{-1}$ for the respective treatments. Although the differences between the same degradation classes across locations may seem minimal, one should pay particular attention to the contribution of SOC to the total system $\mathrm{C}$ stock in every forest condition at each area. For example, in the Andes, SOC in DEF represented nearly $92 \%$ of total C, while in the Coastal range its contribution was $96 \%$. This means that $C$ stocks in aboveground tree biomass were $8 \%$ and $4 \%$ of total $C$ in the Andean and Coastal DEF, respectively, or half as much in the latter case.

Figure 3B shows that the $C$ stocks in tree biomass that were calculated from the 2015 inventory were significantly greater in Andean UNF than DEF, maintaining the same four-fold magnitude difference that was observed in 2013. The same trend was found in the Coastal forests, with the 
exception that the $C$ stock in UNF was significantly higher than PDF (by 2.5 times), which in turn was also higher than DEF (by 3.5 times) $(p<0.05)$. It should also be noted that although $C$ stocks were nearly twice as large in the Andean DEF and PDF, as compared with Coastal forests under the same conditions, they were $21 \%$ higher in the Coastal than Andean UNF (77.2 vs. $\left.63.7 \mathrm{Mg} \cdot \mathrm{C} \cdot \mathrm{ha}^{-1}\right)$.

Regarding SOC stocks among forest conditions, they were significantly higher $(p<0.05)$ in UNF than DEF and PDF in the Andes and the Coast. Ecosystem C stocks were 239, 175, and $149 \mathrm{Mg} \cdot \mathrm{ha}^{-1}$ in the Andean UNF, PDF, and DEF, respectively, while in the Coastal mountains, they were 240, 165, and $153 \mathrm{Mg} \cdot \mathrm{ha}^{-1}$ for the respective treatments. Furthermore, comparing UNF to DEF at both locations, the contribution of aboveground tree biomass to total $C$ was 2.5 times larger in UNF than DEF of the Andes ( $27 \%$ vs. $11 \%$ ), and 5 times larger in UNF than DEF of the Coast ( $32 \%$ vs. $6 \%$ ).

When comparing Figure $3 \mathrm{~A}, \mathrm{~B}$, it is interesting to see that the $\mathrm{C}$ stocks in tree biomass increased by 3.0, 9.6, and $14.2 \mathrm{Mg} \cdot \mathrm{ha}^{-1}$ in the Andean DEF, PDF and UNF, respectively, while in the Coastal mountains, the increase was $3.2,8.7$ and $17.0 \mathrm{Mg} \cdot \mathrm{ha}^{-1}$ for the respective treatments. With respect to $\mathrm{C}$ stocks in SOM, there was not any overall significant difference between the years, although SOC stocks tended to be slightly lower in 2015. However, additional measurements over a longer time span (5-10 years) would likely show higher SOC stocks. Finally, total system C stocks were generally higher in 2015 than 2013, with the largest increases found in UNF at both sites.

\subsection{Soil Bulk Density}

Bulk density of soils at $0-40 \mathrm{~cm}$ depth in Andean and Coastal mountain forests is presented in Table 2. Bulk density was significantly lower in the Andean UNF than in DEF at $0-5 \mathrm{~cm}$ depth, and lower in PDF than in DEF at 20-40 cm depth. It was also lower at 0-5 and 20-40 cm depths in the Coastal UNF. In DEF and PDF at both locations, bulk density did not show any consistent trends, especially in the intermediate degradation condition.

Table 2. Soil bulk density $\left(\mathrm{g} \cdot \mathrm{cm}^{-3}\right.$ ) of Santa Bárbara soil (Medial, amorphic, mesic Typic Hapludands) and Nahuelbuta soil (very fine, mixed, semiactive, mesic Typic Paleudults) at 0-5, 5-20, and 20-40 cm depths in degraded (DEF), partly-degraded (PDF), and undisturbed (UNF) Nothofagus forests of the Andean and Coastal mountains of south central Chile. Measurements were taken in September 2013 (average \pm standard deviation).

\begin{tabular}{|c|c|c|c|c|c|c|c|}
\hline \multirow{2}{*}{ Site } & \multirow{2}{*}{ Condition } & Depth & Bulk Density & \multirow{2}{*}{ Site } & \multirow{2}{*}{ Condition } & Depth & Bulk Density \\
\hline & & $(\mathrm{cm})$ & $\left(\mathrm{g} \cdot \mathrm{cm}^{-3}\right)$ & & & $(\mathrm{cm})$ & $\left(\mathrm{g} \cdot \mathrm{cm}^{-3}\right)$ \\
\hline \multirow{9}{*}{ Andes } & \multirow{3}{*}{ DEF } & $0-5$ & $0.96 \pm 0.05 \mathrm{a} \mathrm{A}$ & \multirow{9}{*}{ Coast } & \multirow{3}{*}{ DEF } & $0-5$ & $0.85 \pm 0.08$ a A \\
\hline & & $5-20$ & $0.84 \pm 0.03 \mathrm{~b} \mathrm{AB}$ & & & $5-20$ & $1.02 \pm 0.09 \mathrm{~b} \mathrm{~A}$ \\
\hline & & $20-40$ & $0.80 \pm 0.05 \mathrm{~b} \mathrm{~A}$ & & & $20-40$ & $1.08 \pm 0.03 \mathrm{~b} \mathrm{~A}$ \\
\hline & \multirow{3}{*}{ PDF } & $0-5$ & $0.89 \pm 0.12 \mathrm{a} A$ & & \multirow{3}{*}{ PDF } & $0-5$ & $1.13 \pm 0.13$ a B \\
\hline & & $5-20$ & $0.98 \pm 0.14 \mathrm{ab} \mathrm{A}$ & & & $5-20$ & $1.02 \pm 0.13 \mathrm{a} \mathrm{A}$ \\
\hline & & $20-40$ & $1.22 \pm 0.19 \mathrm{~b} \mathrm{~B}$ & & & $20-40$ & $1.00 \pm 0.11 \mathrm{a} \mathrm{AB}$ \\
\hline & \multirow{3}{*}{ UNF } & $0-5$ & $0.70 \pm 0.04$ a B & & \multirow{3}{*}{ UNF } & $0-5$ & $0.73 \pm 0.03$ a C \\
\hline & & $5-20$ & $0.80 \pm 0.02 \mathrm{~b} \mathrm{~B}$ & & & $5-20$ & $0.88 \pm 0.24 \mathrm{ab} \mathrm{A}$ \\
\hline & & $20-40$ & $0.86 \pm 0.04 \mathrm{~b} \mathrm{~A}$ & & & $20-40$ & $0.93 \pm 0.09 \mathrm{~b} \mathrm{~B}$ \\
\hline
\end{tabular}

Values with the same lower case letter among the three depths and within a level of degradation at a same site are not significantly different (Tukey's HSD test, ${ }^{*} p<0.05$ ). Values with the same higher case letter within a same depth and site and among the distinct levels of degradations are not significantly different (Student's $t$ test, $\left.{ }^{* *} p<0.05\right)$.

Bulk density usually increased with increasing depth, as expected, except for the Andean DEF where it was significantly higher $(p<0.05)$ at $0-5 \mathrm{~cm}$ depth, probably due to animal trampling on the soil. It was also significantly lower at $0-5$ than $20-40 \mathrm{~cm}$ depths in the Andean PDF, and at $0-5$ then $5-40 \mathrm{~cm}$ depths in the Coastal DEF. Finally, the lowest bulk density $\left(0.70 \mathrm{~g} \cdot \mathrm{cm}^{-3}\right)$ was found at $0-5 \mathrm{~cm}$ depth in the Andean UNF, which was similarly observed in the Coastal UNF $\left(0.73 \mathrm{~g} \cdot \mathrm{cm}^{-3}\right)$.

In the Andes, bulk density at $0-5 \mathrm{~cm}$ depth was significantly lower $(p<0.05)$ in UNF than DEF and PDF, whereas in the Coast, it was significantly lower in UNF. At 5-20 cm depth, bulk density was 
significantly higher in the Andean PDF than UNF only. Lastly, at 20-40 cm depth, bulk density in the Andean site had the significantly highest value in PDF as compared with the other conditions; in the Coastal site, it was significantly lower only in UNF than DEF.

\subsection{C concentrations in Soil Fractions}

\subsubsection{Andean Mountain Forests}

Table 3 shows that in the first measurement period (2013), the mean SOC concentrations (\%) within the LF were statistically higher $(p<0.01)$ in the Andean UNF than DEF at $0-20 \mathrm{~cm}$ depth $(36.2 \%$ vs. $32.9 \%$, i.e., $10 \%$ higher in the UNF), and also higher in the macroaggregates (124\% higher) and microaggregates ( $17 \%$ higher) at $0-5$ and $5-20 \mathrm{~cm}$ depths, respectively.

Table 3. Mean soil organic carbon (C) concentrations (\%) at 0-5, 5-20, and 20-40 cm depths in the light fraction (LF), and $>212 \mu \mathrm{m}, 212-53 \mu \mathrm{m}$, and $<53 \mu \mathrm{m}$ fractions of Santa Bárbara soil (Medial, amorphic, mesic Typic Hapludands) in degraded (DEF), partly-degraded (PDF), and undisturbed (UNF) Nothofagus forests of the Andean mountains of south central Chile. Measurements were taken in September 2013 and 2015 (average \pm standard deviation).

\begin{tabular}{|c|c|c|c|c|c|c|}
\hline \multirow{3}{*}{ Year } & \multirow{3}{*}{ Depth $(\mathrm{cm})$} & \multirow{3}{*}{$\begin{array}{c}\text { Level of } \\
\text { Degradation }\end{array}$} & \multicolumn{4}{|c|}{ Organic C (\%) } \\
\hline & & & \multicolumn{4}{|c|}{ Soil Fraction } \\
\hline & & & Light Fraction (LF) & $>212 \mu \mathrm{m}$ & $212-53 \mu \mathrm{m}$ & $<53 \mu \mathrm{m}$ \\
\hline \multirow{9}{*}{2013} & \multirow{3}{*}{$0-5$} & DEF & $31.26 \pm 0.34 \mathrm{a} \mathrm{A} \mathrm{a}^{\prime}$ & $1.32 \pm 0.06 \mathrm{a} \mathrm{E} \mathrm{a}^{\prime}$ & $4.53 \pm 0.28$ a BCDE $\mathrm{a}^{\prime}$ & $7.48 \pm 0.28 \mathrm{a} \mathrm{B} \mathrm{a}^{\prime}$ \\
\hline & & PDF & $33.37 \pm 2.68 \mathrm{ab} \mathrm{A} \mathrm{a}^{\prime}$ & $1.34 \pm 0.70 \mathrm{ab} \mathrm{B} \mathrm{a}^{\prime}$ & $5.15 \pm 1.78 \mathrm{a} \mathrm{B} \mathrm{a}^{\prime}$ & $6.92 \pm 1.68 \mathrm{a} \mathrm{B} \mathrm{a}^{\prime}$ \\
\hline & & UNF & $37.19 \pm 0.53 \mathrm{~b} \mathrm{~A} \mathrm{a}^{\prime}$ & $2.95 \pm 0.06 \mathrm{~b} \mathrm{~F} \mathrm{a}^{\prime}$ & $6.73 \pm 1.69$ a CDE $a^{\prime}$ & $8.27 \pm 0.04 \mathrm{a} \mathrm{C} \mathrm{a}^{\prime}$ \\
\hline & \multirow{3}{*}{$5-20$} & DEF & $33.56 \pm 0.08 \mathrm{a} \mathrm{A} \mathrm{a}^{\prime}$ & $1.40 \pm 0.16 \mathrm{a} \mathrm{E} \mathrm{a}^{\prime}$ & $2.94 \pm 0.52 \mathrm{a} \mathrm{CDE} \mathrm{a}^{\prime}$ & $6.14 \pm 0.19 \mathrm{a} \mathrm{BC}^{\prime}$ \\
\hline & & PDF & $32.43 \pm 3.08 \mathrm{ab} \mathrm{A} \mathrm{a}^{\prime}$ & $1.10 \pm 0.85 \mathrm{a} \mathrm{B} \mathrm{a}^{\prime}$ & $2.33 \pm 1.31 \mathrm{a} \mathrm{B} \mathrm{a}^{\prime}$ & $4.48 \pm 3.20 \mathrm{ab} \mathrm{B} \mathrm{a}^{\prime}$ \\
\hline & & UNF & $35.83 \pm 0.10 \mathrm{~b} \mathrm{~A} \mathrm{a}^{\prime}$ & $2.43 \pm 0.69 \mathrm{a} \mathrm{F} \mathrm{a}^{\prime}$ & $4.66 \pm 0.85 \mathrm{a} \mathrm{DEF} \mathrm{a}^{\prime}$ & $7.20 \pm 0.04 \mathrm{bCD} \mathrm{a}^{\prime}$ \\
\hline & \multirow{3}{*}{$20-40$} & DEF & $31.70 \pm 2.91 \mathrm{a} \mathrm{A} \mathrm{a}^{\prime}$ & $1.62 \pm 0.80 \mathrm{a} \mathrm{DE} \mathrm{a}^{\prime}$ & $2.49 \pm 0.54 \mathrm{a} \mathrm{CDE} \mathrm{a}^{\prime}$ & $5.17 \pm 0.37 \mathrm{a} \mathrm{BCD} \mathrm{a}^{\prime}$ \\
\hline & & PDF & $36.61 \pm 4.25 \mathrm{a} \mathrm{A} \mathrm{a}^{\prime}$ & $0.62 \pm 0.75 \mathrm{a} \mathrm{B} \mathrm{a}^{\prime}$ & $1.24 \pm 1.40 \mathrm{a} \mathrm{B} \mathrm{a}^{\prime}$ & $2.72 \pm 3.12 \mathrm{a} \mathrm{B} \mathrm{a}^{\prime}$ \\
\hline & & UNF & $30.33 \pm 0.18 \mathrm{a} \mathrm{B} \mathrm{a}^{\prime}$ & $2.12 \pm 1.49 \mathrm{a} \mathrm{F} \mathrm{a}^{\prime}$ & $3.28 \pm 1.31 \mathrm{a} \mathrm{EF} \mathrm{a}^{\prime}$ & $5.07 \pm 1.16$ a CDEF a ${ }^{\prime}$ \\
\hline \multirow{9}{*}{2015} & \multirow{3}{*}{$0-5$} & DEF & $31.29 \pm 1.82 \mathrm{a} \mathrm{A} \mathrm{a}^{\prime}$ & $0.73 \pm 0.00 \mathrm{a} \mathrm{D} \mathrm{b}^{\prime}$ & $5.19 \pm 1.13 \mathrm{a} \mathrm{BC} \mathrm{a}^{\prime}$ & $7.47 \pm 1.32 \mathrm{a} \mathrm{B} \mathrm{a}^{\prime}$ \\
\hline & & PDF & $33.20 \pm 2.11 \mathrm{a} \mathrm{A} \mathrm{a}^{\prime}$ & $0.82 \pm 0.28 \mathrm{a} \mathrm{DE}^{\prime}$ & $5.43 \pm 0.63 \mathrm{a} \mathrm{BC}^{\prime}$ & $7.20 \pm 0.69 \mathrm{a} \mathrm{B} \mathrm{a}^{\prime}$ \\
\hline & & UNF & $35.41 \pm 2.35 \mathrm{a} \mathrm{A} \mathrm{a}^{\prime}$ & $1.36 \pm 0.18 \mathrm{~b} \mathrm{BC}^{\prime}$ & $8.79 \pm 2.80 \mathrm{a} \mathrm{B} \mathrm{a}^{\prime}$ & $8.10 \pm 2.32 \mathrm{a} \mathrm{BC}^{\prime}$ \\
\hline & \multirow{3}{*}{$5-20$} & DEF & $31.95 \pm 1.29 \mathrm{a} \mathrm{A} \mathrm{a}^{\prime}$ & $0.69 \pm 0.04 \mathrm{a} \mathrm{D} \mathrm{b}^{\prime}$ & $3.42 \pm 0.40 \mathrm{a} \mathrm{CD} \mathrm{a}^{\prime}$ & $5.86 \pm 0.13$ a BC $\mathrm{a}^{\prime}$ \\
\hline & & PDF & $30.93 \pm 0.37 \mathrm{a} \mathrm{A} \mathrm{a}^{\prime}$ & $0.45 \pm 0.06 \mathrm{~b} \mathrm{E} \mathrm{a}^{\prime}$ & $1.98 \pm 0.24{\mathrm{~b} \mathrm{CDE} \mathrm{a}^{\prime}}^{\prime}$ & $4.13 \pm 0.98 \mathrm{~b} \mathrm{BCD} \mathrm{a}^{\prime}$ \\
\hline & & UNF & $33.78 \pm 2.71 \mathrm{a} \mathrm{A} \mathrm{a}^{\prime}$ & $1.26 \pm 0.18 \mathrm{c} \mathrm{BC} \mathrm{b}^{\prime}$ & $5.44 \pm 1.21 \mathrm{c} \mathrm{BC} \mathrm{a}^{\prime}$ & $6.75 \pm 0.72 \mathrm{c} \mathrm{BC} \mathrm{a}^{\prime}$ \\
\hline & \multirow{3}{*}{$20-40$} & DEF & $33.10 \pm 1.58 \mathrm{a} \mathrm{A} \mathrm{a}^{\prime}$ & $0.55 \pm 0.10 \mathrm{ab} \mathrm{D} \mathrm{a}^{\prime}$ & $2.42 \pm 0.21 \mathrm{a} \mathrm{CD} \mathrm{a}^{\prime}$ & $4.50 \pm 0.04 \mathrm{a} \mathrm{BC}^{\prime}$ \\
\hline & & PDF & $32.61 \pm 1.18 \mathrm{a} \mathrm{A} \mathrm{a}^{\prime}$ & $0.34 \pm 0.07 \mathrm{a} \mathrm{E} \mathrm{a}^{\prime}$ & $1.07 \pm 0.53 \mathrm{a} \mathrm{DE} \mathrm{a}^{\prime}$ & $2.71 \pm 1.43 \mathrm{a} \mathrm{CDE} \mathrm{a}^{\prime}$ \\
\hline & & UNF & $33.70 \pm 4.02 \mathrm{a} \mathrm{A} \mathrm{a}^{\prime}$ & $0.95 \pm 0.12 \mathrm{~b} \mathrm{C} \mathrm{a}^{\prime}$ & $3.39 \pm 0.10 \mathrm{~b} \mathrm{BC}^{\prime}$ & $4.66 \pm 0.24 \mathrm{a} \mathrm{BC}^{\prime}$ \\
\hline
\end{tabular}

Values with the same lower case letter among levels of degradation and within a same year, depth, and soil fraction are not significantly different (Student's $t$ test, ${ }^{* *} p<0.01$ ). Values with the same higher case letter among the three depths and one level of degradation between distinct soil fractions are not significantly different (Tukey's HSD test, * $p<0.05)$. Values with the same lower case letter $\left(\mathrm{a}^{\prime}\right.$ or $\left.\mathrm{b}^{\prime}\right)$ between years and within a same depth, level of degradation, and soil fraction are not significantly different (Student's $t$ test, ${ }^{*} p<0.05$ ).

In the second period (2015), SOC concentrations in the $>212 \mu \mathrm{m}$ fraction were significantly higher $(p<0.01)$ in Andean UNF than DEF at $0-5$ and $5-20 \mathrm{~cm}$ depths (86 and $83 \%$ higher, respectively). In the 212-53 $\mu \mathrm{m}$ fraction, SOC in UNF was 63 and $40 \%$ higher at 0-20 and 20-40 cm depths, respectively, than in DEF. Lastly, in $<53 \mu \mathrm{m}$ fraction, the only significant difference was found at $5-20 \mathrm{~cm}$ depth, where SOC was $15 \%$ higher in UNF than DEF. It is interesting to note that at 5-20 and 20-40 cm depths, SOC in the macro-, meso-, and microaggregate fractions decreased in the order UNF > DEF > PDF.

Measured C concentrations in 2013 (Table 3) in the LF of Andean DEF and PDF soils were significantly higher $(p<0.05)$ than in any of the other three fractions. The $C$ concentrations in the LF of UNF soils followed the same trend, with the exception that it was significantly lower at 20-40 than at $0-5$ and $5-20 \mathrm{~cm}$ depths. SOC in macroaggregates of Andean UNF was significantly lower $(p<0.05)$ than in meso- and microaggregates at $0-5 \mathrm{~cm}$ depth (Table 4). SOC was also significantly lower than in 
microaggregates at 5-20 cm depth. With respect to DEF, SOC was found to be significantly lower in macro- than microaggregates at $0-5$ and $5-20 \mathrm{~cm}$ depths.

Table 4. Mean soil organic carbon (C) concentrations (\%) at 0-5, 5-20, and 20-40 cm depths in the light fraction (LF), and $>212 \mu \mathrm{m}, 212-53 \mu \mathrm{m}$, and $<53 \mu \mathrm{m}$ fractions of Nahuelbuta soil (very fine, mixed, semiactive, mesic Typic Paleudults) in degraded (DEF), partly-degraded (PDF), and undisturbed (UNF) Nothofagus forests of the Coastal mountains of south central Chile. Measurements were taken in September 2013 and 2015 (average \pm standard deviation).

\begin{tabular}{|c|c|c|c|c|c|c|}
\hline \multirow{3}{*}{ Year } & \multirow{3}{*}{ Depth (cm) } & \multirow{3}{*}{$\begin{array}{c}\text { Level of } \\
\text { Degradation }\end{array}$} & \multicolumn{4}{|c|}{ Organic C (\%) } \\
\hline & & & \multicolumn{4}{|c|}{ Soil Fraction } \\
\hline & & & Light Fraction (LF) & $>212 \mu \mathrm{m}$ & $212-53 \mu \mathrm{m}$ & $<53 \mu \mathrm{m}$ \\
\hline \multirow{7}{*}{2013} & \multirow{2}{*}{$0-5$} & PDF & $32.12 \pm 2.64 \mathrm{a} \mathrm{A} \mathrm{a}^{\prime}$ & $1.37 \pm 0.06 \mathrm{a} \mathrm{CD} \mathrm{a}^{\prime}$ & $5.16 \pm 0.95 \mathrm{a} \mathrm{BCD}^{\prime}$ & $7.26 \pm 1.16 \mathrm{a} \mathrm{B} \mathrm{a}^{\prime}$ \\
\hline & & UNF & $37.29 \pm 1.38 \mathrm{~b} \mathrm{~A} \mathrm{a}^{\prime}$ & $1.26 \pm 0.28 \mathrm{a} \mathrm{D} \mathrm{a}^{\prime}$ & $7.29 \pm 1.45 \mathrm{a} \mathrm{B} \mathrm{a}^{\prime}$ & $8.32 \pm 1.20 \mathrm{a} \mathrm{B} \mathrm{a}^{\prime}$ \\
\hline & \multirow{2}{*}{$5-20$} & DEF & $29.91 \pm 3.46 \mathrm{a} \mathrm{A} \mathrm{a}^{\prime}$ & $1.52 \pm 0.33 \mathrm{a} \mathrm{BC} \mathrm{a}^{\prime}$ & $3.78 \pm 0.41 \mathrm{a} \mathrm{BC}^{\prime}$ & $6.34 \pm 0.42 \mathrm{a} \mathrm{BC}^{\prime}$ \\
\hline & & UNF & $37.23 \pm 1.75 \mathrm{~b} \mathrm{~A} \mathrm{a}^{\prime}$ & $1.40 \pm 0.38 \mathrm{a} \mathrm{D} \mathrm{a}^{\prime}$ & $4.71 \pm 0.89 \mathrm{a} \mathrm{BCD} \mathrm{a}^{\prime}$ & $7.31 \pm 0.68 \mathrm{a} \mathrm{B} \mathrm{a}^{\prime}$ \\
\hline & \multirow{3}{*}{$20-40$} & DEF & $35.35 \pm 2.48 \mathrm{a} \mathrm{A} \mathrm{a}^{\prime}$ & $0.76 \pm 0.25 \mathrm{a} \mathrm{C} \mathrm{a}^{\prime}$ & $1.99 \pm 0.66 \mathrm{a} \mathrm{BC} \mathrm{a}^{\prime}$ & $4.01 \pm 0.70 \mathrm{a} \mathrm{BC} \mathrm{a}^{\prime}$ \\
\hline & & PDF & $32.36 \pm 0.08 \mathrm{a} \mathrm{A} \mathrm{a}^{\prime}$ & $0.74 \pm 0.40 \mathrm{a} \mathrm{D} \mathrm{a}^{\prime}$ & $2.06 \pm 1.21 \mathrm{a} \mathrm{BCD} \mathrm{a}^{\prime}$ & $4.66 \pm 1.83 \mathrm{ab} \mathrm{BCD} \mathrm{a^{ \prime }}$ \\
\hline & & UNF & $36.57 \pm 0.68 \mathrm{~b} \mathrm{~A} \mathrm{a}^{\prime}$ & $0.93 \pm 0.23 \mathrm{a} \mathrm{D} \mathrm{a}^{\prime}$ & $3.22 \pm 0.91 \mathrm{a} \mathrm{CD} \mathrm{a}^{\prime}$ & $6.15 \pm 0.99 \mathrm{~b} \mathrm{BC}^{\prime}$ \\
\hline \multirow{6}{*}{2015} & \multirow[b]{2}{*}{$0-5$} & DEF & $29.45 \pm 1.73 \mathrm{a} \mathrm{A} \mathrm{a}^{\prime}$ & $0.44 \pm 0.05 \mathrm{a} \mathrm{F} \mathrm{b}^{\prime}$ & $4.43 \pm 0.02 \mathrm{a} \mathrm{CD} \mathrm{b}^{\prime}$ & $7.95 \pm 0.74 \mathrm{a} \mathrm{B} \mathrm{a}^{\prime}$ \\
\hline & & PDF & $31.78 \pm 2.30 \mathrm{a} \mathrm{A} \mathrm{a}^{\prime}$ & $0.83 \pm 0.06 b_{D E} b^{\prime}$ & $5.05 \pm 1.49 \mathrm{a} \mathrm{BCD} \mathrm{a}^{\prime}$ & $7.85 \pm 1.15 \mathrm{a} \mathrm{B} \mathrm{a}^{\prime}$ \\
\hline & $5-20$ & UNF & $37.97 \pm 1.36 \mathrm{~b} \mathrm{~A} \mathrm{a}^{\prime}$ & $0.60 \pm 0.12 \mathrm{a} \mathrm{C}^{\prime}$ & $4.46 \pm 2.17 \mathrm{a} \mathrm{BC}^{\prime}$ & $7.48 \pm 2.28 \mathrm{a} \mathrm{BC}^{\prime}$ \\
\hline & \multirow{3}{*}{$20-40$} & DEF & $29.84 \pm 1.26 \mathrm{a} \mathrm{A} \mathrm{b}^{\prime}$ & $0.35 \pm 0.04 \mathrm{a} \mathrm{F} \mathrm{b}^{\prime}$ & $1.49 \pm 0.14 \mathrm{a} \mathrm{DEF} \mathrm{a}^{\prime}$ & $3.68 \pm 0.63 \mathrm{a} \mathrm{CDE} \mathrm{a}^{\prime}$ \\
\hline & & PDF & $33.28 \pm 1.74 \mathrm{ab} \mathrm{A} \mathrm{a}^{\prime}$ & $0.45 \pm 0.18 \mathrm{a} \mathrm{E} \mathrm{a}^{\prime}$ & $1.43 \pm 0.08 \mathrm{a} \mathrm{DE} \mathrm{a}^{\prime}$ & $3.48 \pm 0.06$ a CDE $\mathrm{a}^{\prime}$ \\
\hline & & UNF & $35.74 \pm 1.98 \mathrm{~b} \mathrm{~A} \mathrm{a}^{\prime}$ & $0.54 \pm 0.26 \mathrm{a} \mathrm{C}^{\prime}$ & $3.15 \pm 2.48 \mathrm{a} \mathrm{BC}^{\prime}$ & $5.61 \pm 2.63 \mathrm{a} \mathrm{BC} \mathrm{a}^{\prime}$ \\
\hline
\end{tabular}

Values with the same lower case letter among levels of degradation and within a same year, depth, and soil fraction are not significantly different (Student's $t$ test, ${ }^{* *} p<0.01$ ). Values with the same higher case letter among the three depths and one level of degradation between distinct soil fractions are not significantly different (Tukey's HSD test, * $p<0.05)$. Values with the same lower case letter $\left(\mathrm{a}^{\prime}\right.$ or $\left.\mathrm{b}^{\prime}\right)$ between years and within a same depth, level of degradation, and soil fraction are not significantly different (Student's $t$ test, ${ }^{*} p<0.05$ ).

Regarding the SOC concentrations measured in 2015 in PDF, they were significantly lower $(p<0.05)$ in macro- than in meso- and microaggregates at $0-5 \mathrm{~cm}$ depth, and significantly lower in macro- than in microaggregates at $5-20 \mathrm{~cm}$ depth (Table 4). Also, in meso- and microaggregates, SOC was higher $(p<0.05)$ at $0-5$ than at $20-40 \mathrm{~cm}$ depths only. In DEF, SOC was significantly lower in macro- than meso- and microaggregates ( 7 and 10 times less, respectively) at $0-5 \mathrm{~cm}$ depth, and lower in macro- than microaggregates at 5-20 cm (8.5 times) and 20-40 cm (by 8 times) depths.

The measurements of SOC between the 2013-2015 period indicated that SOC contents were significantly lower in 2015 than in 2013 in macroaggregates at 0-5 and 5-20 cm depths in Andean DEF and UNF (Table 3). Specifically, at 0-5 cm depth, SOC contents were 1.8 and 2.2 times lower in DEF and UNF, respectively; while at 5-20 cm depth, they were 2.0 and 1.9 times lower, respectively.

\subsubsection{Coastal Mountain Forests}

Table 4 shows that in 2013, SOC within the LF was significantly higher $(p<0.01)$ in the Coastal UNF than in PDF and DEF at $0-5,5-20$, and $20-40 \mathrm{~cm}$ depths. The organic $C$ concentrations within the LF at $0-20 \mathrm{~cm}$ depth were $30.3,31.5$, and $37.3 \%$ in DEF, PDF, and UNF, respectively. SOC in UNF was also $53 \%$ higher within the microaggregates at $20-40 \mathrm{~cm}$ depth than in DEF only, with the difference being highly significant. At $0-40 \mathrm{~cm}$ depth, SOC in the LF was 12 and $16 \%$ higher in UNF than DEF and PDF, respectively. Additionally, SOC was $30 \%$ higher in the $<53-\mu \mathrm{m}$ fraction in UNF as compared with DEF, with all these differences being significant.

In 2015, the SOC concentration in mesoaggregates at $0-5 \mathrm{~cm}$ depth was statistically higher $(p<0.05)$ than only the $20-40 \mathrm{~cm}$ depth (Table 4$)$. In DEF, SOC in microaggregates was statistically 
higher at $0-5$ than at $20-40 \mathrm{~cm}$ depths (by over two folds). It was significantly lower in macrothan meso- and microaggregates (10 and 18 times, respectively), and in meso- than microaggregates (1.8 times) at $0-5 \mathrm{~cm}$ depth. At 5-20 and $20-40 \mathrm{~cm}$ depths, SOC was significantly lower in macro- than microaggregates (11 times lower).

Over the two year period, the SOC contents in 2015 were significantly lower than those in 2013 in the LF at 20-40 cm depth in DEF only, and in macroaggregates at all depths in almost all levels of degradation in the Coastal mountains (Table 4). In macroaggregates, SOC contents were 2.7, 1.7, and 1.9 times less in DEF, PDF, and UNF, respectively, at $0-5 \mathrm{~cm}$ depth, whereas at 5-20 $\mathrm{cm}$ depth, they were $2.5,1.8$, and 2.3 times less in the same sequence of forest degradation. Also, at $20-40 \mathrm{~cm}$ depth, SOC was 2.2 times less in DEF.

Finally, although direct comparisons between both sites cannot be made because of differences in soil orders and climate (precipitation), one should note that in 2013, SOC at 0-20 and 20-40 cm depths in macroaggregates was 1.9 and 2.3 times larger in the Andean than Coastal UNF, respectively, and it was over twice as much at $20-40 \mathrm{~cm}$ depth in the Andean DEF as compared with the Coastal DEF. Additionally, in 2015, SOC concentrations in macroaggregates were 2.1 and 1.8 times larger at the same depth sequence in the Andean than Coastal UNF.

\subsection{Century Model Simulations}

In order to understand the soil $C$ sequestration potential of the most degraded forests, we modeled SOC changes over the next 200 years using the Century model, which was run for both soil types and locations (Table 5). The degraded condition corresponds to a forest that has been strongly grazed by cattle and sheep until the beginning of this investigation. One possible scenario would be to maintain the heavy grazing on grass pasture component (traditional pastoral management), whereas the other would consist of improving the pasture component with grass clover in order to perform light grazing (improved silvopastoralism). Given the lack of grass- and rangelands in the studied regions, open degraded forests with the presence of natural pasture are most likely to continue being used by local "campesinos". The simulations (Table 5) indicated that under improved silvopastoral management, the recovery of lost soil organic $C$ would be slow, with the higher rates of $C$ sequestration in soils occurring within the first 50 years. The volcanic Andisol soil would have lower increases of total organic C compared to the non-volcanic Ultisol soil (i.e., 7\% vs. 15\% increases between 2016 and 2216 in degraded Andisol and Ultisol, respectively). Additionally, it is interesting to note that the 2016 simulated values of 76.17 and $92.25 \mathrm{Mg} \cdot \mathrm{ha}^{-1}$ in the Andisol and Ultisol, respectively, are relatively similar (less than $5 \%$ difference for both soils) to those calculated at $0-20 \mathrm{~cm}$ depth [33], which indicates the accuracy of the calibration process and reliability of the Century model when performing long term simulations of carbon sequestration potentials of indigenous forests (Table 5).

Although the total $C$ stock in soil, as simulated using Century concurred with the actual measured values, there were discrepancies between the relative proportions of $C$ stocks of the specific model pools and the SOC content of the separate fractions. The Century model indicated relatively similar amounts of $\mathrm{C}$ in the slow and passive fractions of $\mathrm{SOM}$, whereas the measured $\mathrm{C}$ was generally higher in the $<53 \mu \mathrm{m}$ (passive) fraction than the other fractions at both sites and years (Tables 3 and 4). 
Table 5. Projections of soil organic carbon (C) stocks in soil (0-20 cm depth) in degraded Nothofagus forests of the Santa Bárbara soil (medial, amorphic, mesic Typic Hapludands), and Nahuelbuta soil (very fine, mixed, semiactive, mesic Typic Paleudults) of the Andes and Coastal mountain ranges, respectively, of south central Chile as simulated using the Century model. Measurements were taken in September 2013.

\begin{tabular}{|c|c|c|c|c|c|c|c|c|}
\hline \multirow[b]{2}{*}{ Site } & \multirow{2}{*}{$\begin{array}{l}\text { Soil } \\
\text { Order }\end{array}$} & \multirow[b]{2}{*}{ Year } & \multicolumn{6}{|c|}{ Century C $\left(\mathrm{g} \cdot \mathrm{m}^{-2}, 0-20 \mathrm{~cm}\right.$ Depth) } \\
\hline & & & $\begin{array}{l}\text { Silvopastoral } \\
\text { Management }\end{array}$ & $\begin{array}{c}\text { Passive } \\
\text { Pool }\end{array}$ & $\begin{array}{l}\text { Slow } \\
\text { Pool }\end{array}$ & $\begin{array}{l}\text { Active } \\
\text { Pool }\end{array}$ & Total C & $\begin{array}{c}\text { (SOC) } \\
(\%)\end{array}$ \\
\hline \multirow{5}{*}{ Andes } & \multirow{5}{*}{ Andisol } & 2016 & Traditional $^{1}$ & 3960 & 3227 & 238 & 7617 & $(4.4)$ \\
\hline & & 2066 & Improved $^{2}$ & 3979 & 3539 & 223 & 8119 & (4.7) \\
\hline & & 2116 & Improved & 3986 & 3542 & 223 & 8130 & $(4.7)$ \\
\hline & & 2166 & Improved & 3991 & 3543 & 223 & 8136 & $(4.7)$ \\
\hline & & 2216 & Improved & 3997 & 3542 & 223 & 8142 & $(4.7)$ \\
\hline \multirow{5}{*}{ Coast } & \multirow{5}{*}{ Ultisol } & 2016 & Traditional $^{1}$ & 3938 & 4658 & 317 & 9225 & (4.7) \\
\hline & & 2066 & Improved $^{2}$ & 3955 & 5487 & 325 & 10,179 & $(5.2)$ \\
\hline & & 2116 & Improved & 3990 & 5716 & 330 & 10,453 & (5.3) \\
\hline & & 2166 & Improved & 4027 & 5750 & 331 & 10,533 & (5.4) \\
\hline & & 2216 & Improved & 4060 & 5761 & 331 & 10,581 & $(5.4)$ \\
\hline
\end{tabular}

${ }^{1}$ Traditional pastoralism = heavy grazing of grass pasture for three months of each year; ${ }^{2}$ Improved silvopastoralism $=$ light grazing on grass-legume pastures among trees for three months each year.

\section{Discussion}

\subsection{Stocks in Tree Biomass and Soil}

Based on our observation of the forest structure and composition during inventories (Table 1), the Andean PDF was rather similar to the UNF, which could explain why carbon stocks per hectare in aboveground tree biomass were not significantly different. PDF in the Chilean Andes tended to have been subjected to less human-intervention than in the Coastal mountains, coinciding with the lower demographic pressure in the surrounding area. However, DEF in both locations (especially in the Coastal mountains) have been more severely subjected to interventions over the last five decades, mostly by extensive cattle grazing and unsustainable exploitation of the wood resources, resulting in small trees and low stand density (i.e., few tree stems per hectare). This is likely why the $\mathrm{C}$ stock in tree biomass is so low in Andean DEF and even less in the Coastal range.

With respect to the larger $C$ stock in Coastal UNF compared to Andean UNF (60.2 vs. $49.5 \mathrm{Mg} \cdot \mathrm{C} \cdot \mathrm{ha}^{-1}$ in 2013 , and $77.2 \mathrm{vs.} 63.7 \mathrm{Mg} \cdot \mathrm{C} \cdot \mathrm{ha}^{-1}$ in 2015$)$, the differences can be attributed to the higher tree density (50\% of all trees per hectare are Nothofagus obliqua vs. $35 \%$ in the Andean UNF), which compensates for the larger DBH and HT of trees in the Andean UNF. In a previous investigation [25], researchers working with a 150-year-old unmanaged second-growth Nothofagus pumilio forest on an Andisol soil in the Chilean Patagonia reported $229 \mathrm{Mg} \cdot \mathrm{C} \cdot \mathrm{ha}{ }^{-1}$ for aboveground tree biomass, which greatly exceeds the values reported in this study for Nothofagus obliqua. One possible explanation is the totally different stand characteristics of these two Nothofagus species. In the Patagonian study, tree density exceeded 1000 stems.ha ${ }^{-1}$, which is more than twice the densities measured in the Andean and Coastal forests. Additionally, trees in Patagonia belonged to six diameter classes with most of the individuals pertaining to the $30-50 \mathrm{~cm}$ classes. In contrast, trees in Andean and Coastal UNF belonged to 13 and 8 different diameter classes, respectively, with most of the individuals pertaining to the $5-25 \mathrm{~cm}$ classes. Finally, trees in Patagonia were $10 \%$ and $35 \%$ taller than those in Andean and Coastal UNF, respectively.

When making comparisons of the C stocks in tree biomass between 2013 and 2015 at both locations, one may perceive how the gains were affected by the different degradation levels (i.e., the more disturbed the forest, the smaller and less vigorous are the trees, which resulted in lower increases of annual C stocks). This was clearly observed in the inventory that was performed in 2015, as compared with that of 2014, where we found the lowest tree DBH and HT increases, as a result of a 
severe six-month drought in the 2015 summer in south-central Chile. For example, DBH increments were up to four and two times lower in DEF and UNF at both sites, respectively, vs. those measured in 2014. Furthermore, there was no difference in height growth increment in DEF in the 2014-2015 vs. 2013-2014 periods, but the height growth increment was 25\% lower in UNF when comparing the same periods. On the other hand, trees with $\mathrm{DBH}<10 \mathrm{~cm}$ were the most affected, especially in DEF, and many of them were without almost any increment of growth in the last year. Tree mortality was also by far the highest in DEF, per the results of the third inventory.

In DEF of both locations, especially in the Coastal range, we observed an important variation of soil $\mathrm{C}$ concentrations and bulk density across depths because these soils have been highly subjected to interventions over the years. This may explain why their C stocks are slightly higher-although not significantly so- than those of PDF, with the same trend in both sites. The lower C stock variability in the Coastal PDF, compared to the C stock in DEF may explain why it is statistically lower than that of UNF.

As stated by others [34], soil C stock calculation depends on variables such as C concentration, horizon thickness, and bulk density, which all have their own variances and errors. In temperate forests dominated by Nothofagus pumilio in southern Chile, [25,35] the reported SOC stocks were 100 and $102 \mathrm{Mg} \cdot \mathrm{ha}^{-1}$, respectively, which were measured in Andisols at 0-40 cm depth, whereas others [36] reported $132 \mathrm{Mg} \cdot \mathrm{C} \cdot \mathrm{ha}^{-1}$ in Andisols at 0-30 $\mathrm{cm}$ depth under a second-growth N. obliqua forest. While the latter value is more similar to the results obtained in this study in UNF, the reported value of $100 \mathrm{Mg} \cdot \mathrm{C} \cdot \mathrm{ha}^{-1}$ reported by [25] corresponds to a forest subjected to moderate interventions, mostly from light thinning and cattle grazing in the summer months and may therefore be compared to the Andean PDF, with a soil organic C stock in a similar range (119 Mg.C.ha- ${ }^{-1}$ in 2013).

Regarding non-volcanic soils, Stolpe et al. [3] reported substantially lower organic C stocks in an Alfisol soil under highly degraded and typical Acacia caven forests (Espinales) in a semi-arid region of central Chile. In their study, the carbon stock at $0-40 \mathrm{~cm}$ depth was $17.5 \mathrm{Mg} \cdot \mathrm{C} \cdot \mathrm{ha}^{-1}(10 \%-25 \%$ forest cover) and $25.2 \mathrm{Mg} \cdot \mathrm{C} \cdot \mathrm{ha}^{-1}(26 \%-50 \%$ cover $)$ in the degraded and typical conditions, respectively. These results show that the proportion of forest cover is highly related to site degradation, which has a direct effect on the formation of soil organic matter. SOC stocks can vary substantially between ecosystems and depend not only on the soil type, but also on the prevalent climate, management, and vegetation [37], which in turn will affect the quality of plant residues that fall on the ground and the microbial biomass capacity to decompose and incorporate it into the SOM [25].

Although the Coastal DEF is substantially more degraded than the Andean one, as is evidenced by smaller trees and a deficient forest structure and composition as previously discussed, it is interesting to see that its absolute and relative soil C stocks remain slightly higher than in the degraded Andean soil, even more so considering that the Coastal soil is an Ultisol (non-volcanic soil) that is generally characterized by a lower stock of organic C as part of the SOM, compared to Andisols. That the Coastal DEF soil is more degraded than the Andean one, even though it has more total $\mathrm{C}$, is reflected by lower C concentrations in the macro-, meso-, and microaggregate fractions at $20-40 \mathrm{~cm}$ depth in both measurement periods, and in the macro- and mesoaggregate fractions at 0-20 cm depth in 2015 (Tables 3 and 4). A previous investigation [25] which compared degraded pastures with Nothofagus pumilio forests in southern Chile reported similar trends. Undoubtedly, all the numbers presented in Section 3.1 show the strong effect of site disturbance and the resulting degradation over the years, as well as the factor of geographical location (and the corresponding climate in the Coastal mountains, with generally lower annual precipitations) on $\mathrm{C}$ storage potential in native ecosystems.

When comparing SOC stocks between 2013 and 2015 in the different forest conditions at both locations, a possible explanation for the slightly lower values in 2015, although not significant, could be due to the different sampling points where soil samples were extracted between the years. This does not happen when measuring $C$ gains in the aboveground tree biomass because the same individuals are monitored over the years. In 2013, the higher C concentrations in the soil samples (as reflected in 
the LF and macroaggregates shown in Tables 3 and 4) may also be attributed to soil heterogeneity and the presence of C-rich pockets in the surveyed sectors [1,38].

\subsection{Soil Bulk Density}

The more degraded the forests, as caused by higher intervention by humans and grazing by cattle, the more they are usually accompanied by high levels of soil compaction. As a result of increasing soil compaction, bulk density increases not only at the surface but also with increasing soil depth. Bulk density is also affected by soil genesis, whereby the Andean soils tend to have a lower bulk density than those of the Coastal mountains because of their volcanic origin which also favors higher contents of organic matter. The lower bulk density is also accompanied by higher amounts of $\mathrm{C}$ and $\mathrm{N}$ that are sequestered in volcanic soils, with the result that the soils are therefore somewhat protected from mineralization and leaching, and other possible losses from the system [39].

The discrepancies that were observed in PDF could be attributed to the difficulty in finding the "most representative" of the condition in the sense that partial degradation is an intermediate state that is sometimes more similar to full degradation and sometimes more similar to non-degradation states. Also, there is very limited quantitative characterization or metrics that are known that permit a clear definition of this intermediate condition. According to [40], the relation between SOC and the different states of forests remain uncertain. Additionally, given the small variations that may occur in forest $C$ stocks [41], it can be difficult to establish threshold values in order to define degradation levels.

The abnormally high bulk density at $0-5 \mathrm{~cm}$ depth in Andean DEF $\left(0.96 \mathrm{~g} \cdot \mathrm{cm}^{-3}\right)$ and at $20-40 \mathrm{~cm}$ depth in PDF $\left(1.22 \mathrm{~g} \cdot \mathrm{cm}^{-3}\right)$ could be attributed to the presence of horses being grazed throughout the year since plot fencing was established just a month before the period of soil sampling. Ongoing presence of cattle and sheep has also been observed in Coastal DEF and PDF. New measurements of soil bulk density should be performed only in the exclusion plots in order to test this hypothesis. With respect to UNF at both locations, the low soil bulk density at $0-40 \mathrm{~cm}$ depth can probably be explained by the larger amount of roots found in this condition which, according to [42] who studied their effect on several soil parameters in temperate woodlands, contribute to lower the bulk density by action of root penetration across the soil profile.

Panichini et al. reported bulk densities of 0.54 and $0.74 \mathrm{~g} \cdot \mathrm{cm}^{-3}$ at $0-19 \mathrm{~cm}$ and $19-41 \mathrm{~cm}$ depths, respectively, in temperate Nothofagus pumilio rainforests on a Chilean Andisol, whereas the values of our study in the Andean UNF ranged from 0.78 to $0.86 \mathrm{~g} \cdot \mathrm{cm}^{-3}$ at $0-20 \mathrm{~cm}$ and $20-40 \mathrm{~cm}$ depths, respectively [35]. In northern Argentine Patagonia, Candan and Broquen [43] reported an average bulk density of $0.72 \mathrm{~g} \cdot \mathrm{cm}^{-3}$ in the upper $5 \mathrm{~cm}$ of the A-horizon of an Andisol under an unmanaged, almost pristine Nothofagus sp. mixed forest, which is highly similar to the value obtained in Andean UNF at $0-5 \mathrm{~cm}$ depth. On the other hand, Dorner et al. [44] found bulk densities ranging from 0.8 to $1.1 \mathrm{~g} \cdot \mathrm{cm}^{-3}$ in a Chilean prairie (Lolium multiflorum-Avena strigosa) Ultisol without major disturbances, while the bulk density values obtained in this study were $0.84,0.98$, and $1.05 \mathrm{~g} \cdot \mathrm{cm}^{-3}$ in Coastal UNF, DEF, and PDF, respectively, at 0-20 cm depth.

\subsection{Concentrations in Soil Fractions}

As observed in Tables 3 and 4 , the C concentrations within the LF (un-decomposed organic matter of plant origin) were significantly higher $(p<0.05)$ in the Andean UNF than in DEF at $0-20 \mathrm{~cm}$ depth in the first measurement period, and higher in the Coastal UNF than in DEF at all depths in both measurement periods, although no significant differences were found between the two years (except at 20-40 cm depth in the Coastal DEF). This lack of difference is attributed to the relatively short time span, which is not sufficient for any significant changes of SOC in this fraction. This is especially true in the Andes where the level of degradation is lighter, which implies that changes may be more difficult to observe. Also, the different physicochemical properties of Andisols, such as the presence of amorphous clay (allophane or imogolite) having a high specific surface area and a pH-dependent charge, large amounts of humus, high content of water at $1500 \mathrm{kPa}$ tension, high 
phosphate retention, and slow decomposition of incorporated organic materials may also help to provide an explanation for slow changes in SOC [45]. On the other hand, UNF have a larger input of new plant debris (not decomposed) throughout the year than DEF, with a higher diversity and number of species, and a larger litterfall (i.e., constant input of leaves, cones, fruits, and twigs). The LF is a coarse and unstable organic matter, whereby its content in soil tends to be affected by rapid changes (i.e., influenced by the type of management performed) [3,37]. Additionally, according to [46], the LF is highly sensitive to present forest management but not to historical ones. The carbon in mineral dominated aggregates, however, is part of older humic substances and therefore more likely a "historical remnant". This helps understand why Andean and Coastal forests that have not been subjected to interventions (or managed) between 2013 and 2015 have similar C concentrations within their LF at almost all depths.

The fact that $C$ concentrations in macroaggregates $(>212 \mu \mathrm{m})$ were higher in Andean and Coastal UNF than DEF at 0-40 cm depth in both measurement periods shows a condition of better management over the years. The same trends were observed for meso- and microaggregates, although the differences were not always significant, showing that the Andean UNF sequester the largest amount of $C$ in its macro-, meso-, and microaggregates. The most labile fraction $(>212 \mu \mathrm{m})$ is an indicator of sustainable management because its content in the soil changes in the short term (various months to a few years), depending on vegetation, type of management, and equilibrium between plant residue input and subsequent decomposition in the soil $[3,47]$. However, the reasons why $C$ concentrations in macroaggregates at $0-20 \mathrm{~cm}$ depth are significantly lower in 2015 than 2013 remain unclear and cannot be fully explained at this point, even more so considering that sampling plots were fenced at the beginning of the study in order to prevent animal intrusion and any other associated site disturbance, and that this kind of trend did not occur in the other soil fractions. As hypothesized in Section 4.1, however, a specific explanation based on findings of $[1,38]$ might be that the presence of $C$-rich pockets could have been inadvertently included in the first set of sampling points in the surveyed sectors, but absent in the second set. More research is needed to test this hypothesis.

The significantly larger $C$ concentrations in mesoaggregates $(212-53 \mu \mathrm{m})$ at $0-40 \mathrm{~cm}$ depth in UNF vs. DEF in 2015 indicate that these have the best soil quality, which could be attributed to the minimum anthropogenic intervention over the last 50 years [25]. The better quality of organic matter found in UNF at both locations is also reflected by greater presence of $\mathrm{N}-\mathrm{NH}_{4}$ and available $\mathrm{K}$ and $\mathrm{S}$ [48]. The quality of soil organic matter is essential in order to maintain productivity of the forest and assure its long-term sustainability. Soil organic matter increases also allow the sequestration of surplus atmospheric $\mathrm{CO}_{2}$.

Our results for the LF were in the same range as those obtained for macroaggregates by [25] who performed physical fractionation of an Andisol in a Nothofagus pumilio forest. In their study, the LF was not measured independently like in this work, which impedes a direct comparison with organic $C$ concentrations of the respective macroaggregates. Similar ranges of $C$ concentrations were also found at all depths in the meso- and microaggregate fractions.

The observation that organic $C$ concentrations were higher in micro- than in mesoaggregates, and significantly higher than in macroaggregates in all levels of degradation at both sites, is consistent with a study performed by [43] in a Nothofagus sp. mixed forest. These authors reported that the smallest aggregates $(<50 \mu \mathrm{m})$ at $0-5 \mathrm{~cm}$ depth in an Andisol had the highest SOC concentrations comparing with the LF, the 2000-250 and the 250-50- $\mu \mathrm{m}$ size fractions. Additionally, they found that the LF $(8000-2000 \mu \mathrm{m})$ contained the second largest amount of organic $C$, which is also in agreement with our study. Other works (e.g., [49]) have confirmed that large amounts of SOM are required for the formation of bigger aggregates.

Regarding the changes of organic $C$ concentration through the soil profiles from 0 to $40 \mathrm{~cm}$ depth, decreases were found in every level of degradation and location, as expected, with the highest values in the first $5 \mathrm{~cm}$ (Tables 3 and 4). Similar but more pronounced decreases were observed for the $\mathrm{N}$ 
concentrations [50]. As a result, the $\mathrm{C} / \mathrm{N}$ ratios increased with depth, which indicated greater SOM stability with soil depth.

\subsection{Century Model Simulations}

The dissimilarities between modeled and measured SOC values can occur when input values for site characterization do not fully reflect the range of field conditions, when theoretical pools of models are not easily quantifiable in the laboratory, or when the measured fractions have composite characteristics that change with management and the environment [51,52]. Nevertheless, the simulations using the Century model indicated that restoration of organic $C$ in degraded soils would be relatively slow with most $C$ sequestration occurring in soil in the first 50 years (Table 5), after the conversion of the traditional pastoral management (in degraded forests) to systemic and planned silvopastoralism, which emphasizes the importance of useful indicators of soil quality that can rapidly identify soils with unsustainable management long before soil degradation progresses too far. In the future, however, it is hoped that the Century model may be tied to governmental programs for implementing sustainable soil management through " $\mathrm{C}$ credits" for $\mathrm{C}$ sequestration in soil, as outlined in the Kyoto Protocol [53].

\section{Conclusions}

The degraded forests, especially in the Coastal mountains, show a large variation of bulk density and $C$ concentrations in the upper $40 \mathrm{~cm}$ because these soils have been highly subjected to interventions in the last 50 years, mostly by extensive cattle grazing and unsustainable exploitation of wood resources. The generally higher bulk density and lower SOM contents in DEF can also explain why less $\mathrm{C}$ and $\mathrm{N}$ are sequestered (immobilized) in these soils, and subsequently exposed to losses by leaching or runoff. Additionally, these soils are more likely to be disturbed through rain and wind erosion, which accelerates aggregate destruction and consequently, increases SOC losses.

Higher C concentrations in macroaggregates in UNF at 0-40 cm depth-although not always significant-indicate a condition of higher sustainability and better management over the years. The most labile fraction is an indicator of sustainable management because its $C$ content in the soil changes in the short term, depending on vegetation, type of management, etc. Additionally, the significantly larger C concentrations in mesoaggregates at $0-40 \mathrm{~cm}$ depth in UNF in 2015 clearly indicate that these forests have the best soil quality, which could be attributed to the minimum amount of anthropogenic intervention over the last 50 years. The better organic matter quality found in UNF is also reflected by the presence of more $\mathrm{N}_{-} \mathrm{NH}_{4}$ and available $\mathrm{K}$ and $\mathrm{S}$.

Inadequate soil management practices (e.g., non-systemic grazing, overuse of the forest) tend to accelerate SOC mineralization, causing net emissions of $\mathrm{CO}_{2}$. The use of forest degradation and soil quality indicators allows for adequate quantification of the degree of deterioration of Nothofagus forests in south central Chile.

As simulated by the Century model, with the conversion of traditional grazing in degraded forests to a silvopastoral system, considering the synergy between trees and pasture, most SOC sequestration would occur in the next 50 years in the Ultisol, although it is more degraded. This soil would also have the highest increase of total organic C between 2016 and 2216, compared to the volcanic soil. However, besides the uncertainties as to the direction of climate change, where certain coastal areas of Chile are gradually cooling, and other areas warming [54], simulations with Century show that in the time period considered here that the model is far more sensitive to input clay content of the soils than to anticipated climatic variability. That is to say, soil variability in the field can be more important to simulated SOC than climatic change projections on large time scales.

Acknowledgments: We sincerely wish to acknowledge and express our sincere thanks to Elna von Harper from Elnahue Estate near Los Pellines in the Andean Foothills, and "Campesinos" from Chanleo (Nahuelbuta Coastal Range) for hosting the research sites on their properties, to Cristián Hormazábal for field assistance, and to Burkhard Müller-Using for his help with research site selection. The excellent review comments and 
recommendations from three anonymous reviewers were also highly appreciated. This study was funded by a grant from the National Commission for Scientific and Technological Research of the Chilean Government (FONDECYT Project No. 11121279).

Author Contributions: Francis Dube and Neal B. Stolpe conceived, designed, and performed the experiments; Francis Dube and Neal B. Stolpe analyzed the data and wrote the paper.

Conflicts of Interest: The authors declare no conflict of interest.

\section{References}

1. Dube, F.; Espinosa, M.; Stolpe, N.; Zagal, E.; Thevathasan, N.V.; Gordon, A.M. Productivity and carbon storage in silvopastoral systems with Pinus ponderosa and Trifolium spp., plantations and pasture on an Andisol in Patagonia, Chile. Agrofor. Syst. 2012, 86, 113-128. [CrossRef]

2. Krull, E.S.; Baldock, J.A.; Skjemstad, J.O. Importance of mechanism and processes of the stabilization of soil organic matter for modeling carbon turnover. Funct. Plant Biol. 2003, 30, 207-222. [CrossRef]

3. Stolpe, N.; Muñoz, C.; Zagal, E.; Ovalle, C. Modeling soil carbon storage in the Espinal agroecosystem of central Chile. Arid Land Res. Manag. 2008, 22, 148-158. [CrossRef]

4. Carter, M. Soil quality for sustainable land management: Organic matter and aggregation interactions that maintain soil functions. Agron. J. 2002, 94, 38-47. [CrossRef]

5. Parton, W.J.; Schimel, D.S.; Cole, C.V.; Ojima, D.S. Analysis of factors controlling soil organic matter levels in Great Plains grasslands. Soil Sci. Soc. Am. J. 1987, 51, 1173-1179. [CrossRef]

6. Del Pozo, A.; Del Canto, P. Áreas agro Climáticas Productivas en la VII y VIII Regiones; Instituto de Investigaciones Agropecuarias, CRI-Quilamapu, Ministerio de Agricultura: Santiago, Chile, 1999.

7. Stolpe, N. Century simulated organic carbon content in soils of south central Chile with diverse ratios of $1500 \mathrm{kPa}$ water to measured clay. Acta Agric. Scand. Sec. B Plant Soil Sci. 2013, 63, 11-18. [CrossRef]

8. Instituto Forestal (INFOR). Desarrollo de Tecnología Silvícola Productiva como Apoyo para la Implementación de la Ley de Bosque Nativo. Anexo 6. Elaboración de Pautas Silvícolas de Manejo para Renovales; INNOVA/CORFO-09CN14-5854; INFOR: Valdivia, Chile, 2012; pp. 1-28.

9. Dube, F.; Sotomayor, A.; Loewe, V.; Müller-Using, B.; Stolpe, N.; Zagal, E.; Doussoulin, M. Silvopastoral systems in temperate zones of Chile. In Silvopastoral Systems in Southern South America; Peri, P.L., Dube, F., Varella, A.C., Eds.; Springer: Dordrecht, The Netherlands, 2016; Volume 11, pp. 183-211.

10. Müller-Using, B.; University of Concepción, Faculty of Forest Sciences, Concepción, VIII Region, Chile. Personal communication, 2012.

11. Ortega, R.; Rodríguez, I. Manual de Gestión del Medio Ambiente; Mapfre: Santiago, Chile, 1994; pp. 1-343.

12. Instituto Geográfico Militar (IGM). Atlas Geográfico de Chile; Instituto Geográfico Militar: Santiago, Chile, 2005; pp. 1-208.

13. Nations Online Project. One World Nations Online-Countries in the World Satellite Maps. Available online: http:/ / www.nationsonline.org/oneworld/map/chile-political-map.htm (accessed on 20 October 2016).

14. Dirección General de Aeronáutica Civil (DGAC). Dirección Meteorológica de Chile; Dirección General de Aeronáutica Civil: Santiago, Chile; Available online: http://www.meteochile.gob.cl/climas/climas_octava_ region.html (accessed on 1 March 2011).

15. Centro de Informaciones de Recursos Naturales (CIREN). Descripciones de Suelos, Materiales, y Símbolos. Estudio Agrológico VIII Región de Chile; Centro de Informaciones de Recursos Naturales: Santiago, Chile, 1998.

16. Stolpe, N. Descripción de los Principales Suelos de la VIII Región de Chile; Universidad de Concepción: Concepción, Chile, 2006.

17. Soil Survey Staff. In Keys to Soil Taxonomy, 12th ed.Natural Resources Conservation Service, USDA: Washington, DC, USA, 2014.

18. Bahamóndes, C.; Martin, M.; Müller-Using, S.; Rojas, J.; Vergara, G. Case Studies on Measuring and Assessing Forest Degradation-An Operational Approach to Forest Degradation; Forest Resources Assessment Working Paper No. 158; FAO: Roma, Italy, 2009; pp. 1-9.

19. Annighöfer, P.; Beckschäfer, P.; Vor, T.; Ammer, C. Regeneration patterns of European oak species (Quercus petraea (Matt.) Liebl., Quercus robur L.) in dependence of environment and neighborhood. PLoS ONE 2015, 10, e0134935. 
20. Corporación Nacional Forestal (CONAF). Funciones Alométricas para la Determinación de Existencias de Carbono Forestal para la Especie Nothofagus Obliqua (Mirb.) Oerst; Ministerio de Agricultura: Santiago, Chile, 2013; pp. 1-41.

21. Intergovernmental Panel on Climate Change (IPCC). Climate change 2001: The scientific basis. In Contribution of Working Group I to the Third Assessment Report of the Intergovernmental Panel on Climate Change; Houghton, J.T., Ding, Y., Griggs, D.J., Noguer, M., van der Linden, P.J., Dai, X., Mashell, K., Johnson, C.A., Eds.; Cambridge University Press: Cambridge, UK, 2001; pp. 1-881.

22. Blake, G.R. Bulk density. In Methods of Soil Analysis, Part 1; Black, C.A., Ed.; American Society of Agronomy: Madison, WI, USA, 1965; pp. 374-390.

23. Feller, C.; Burtin, G.; Gérard, B.; Balesdent, J. Utilisation des résines sodiques et des ultrasons dans le fractionnement granulométrique de la matière organique des sols: Intérêts et limites. Sciences du Sol 1991, 29, 77-94.

24. Balesdent, J.; Pétraud, J.; Feller, C. Effect of ultrasound on the granulometric distribution of organic matter in soil. Science du Sol 1991, 29, 95-106.

25. Dube, F.; Zagal, E.; Stolpe, N.; Espinosa, M. The influence of land use change on the organic carbon distribution and microbial respiration in a volcanic soil of the Chilean Patagonia. For. Ecol. Manag. 2009, 257, 1695-1704. [CrossRef]

26. Stolpe, N.; Dube, F.; Zagal, E. Calibration of CO2FIX to native forest, pine plantation, and pasture on a volcanic soil of the Chilean Patagonia. Acta Agric. Scand. Sec. B Soil Plant Sci. 2010, 60, 235-244. [CrossRef]

27. Wright, A.F.; Bailey, J.S. Organic carbon, total carbon, and total nitrogen determinations in soils of variable calcium carbonate contents using a LECO CN-2000 dry combustion analyzer. Commun. Soil Sci. Plant Anal. 2001, 32, 3243-3258. [CrossRef]

28. Metherell, A.K.; Harding, L.A.; Cole, C.V.; Parton, W.J. Century Organic Matter Model Environment, Technical Documentation; Great Plains System Research Unit, Technical Report No 4; USDA-ARS: Fort Collins, CO, USA, 1993.

29. DMC. Dirección Meteorológica de Chile. Meteorological Service of Chile, Santiago, Chile. 2015. Available online: www.meteochile.gob.cl (accessed on 1 March 2015).

30. Godoy, R.; Paulino, L.; Oyarzún, C.; Boeckx, P. Atmospheric N deposition in central and southern Chile. An overview. Gayana Bot. 2003, 60, 47-53. [CrossRef]

31. Kelly, R.H.; Parton, W.J.; Crocker, G.H.; Grace, P.R.; Klir, J.; Körschens, M.; Poulton, P.R.; Richter, D.D. Simulating trends in soil organic carbon in long-term experiments using the Century model. Geoderma 1997, 81, 75-90. [CrossRef]

32. SAS Institute Inc. SAS User's Guide: Statistics; SAS Institute Inc.: Cary, NC, USA, 2002.

33. Stolpe, N.B.; Soils and Natural Resources Department, Faculty of Agronomy, University of Concepción, Vicente Méndez 595, Casilla 537, Chillan, Chile. Century model simulations in native forests of Chile. Unpublished data. 2016.

34. Beckert, M.R.; Smith, P.; Lilly, A.; Chapman, S.J. Soil and tree biomass carbon sequestration potential of silvopastoral and woodland-pasture systems in North East Scotland. Agrofor. Syst. 2016, 90, 371-383. [CrossRef]

35. Panichini, M.; Matus, F.; Mora, M.L.; Godoy, R.; Bolan, N.S.; Rumpel, C. Carbon distribution in top- and subsoil horizons of two contrasting Andisol under pasture or forest. Eur. J. Soil Sci. 2012, 63, 616-624. [CrossRef]

36. Huygens, D.; Boeckx, P.; Van Cleemput, O.; Oyarzun, C.; Godoy, R. Aggregate and soil organic carbon dynamics in South Chilean Andisols. Biogeosciences 2005, 2, 159-174. [CrossRef]

37. Zagal, E.; Rodríguez, N.; Vidal, I.; Flores, B. Soil light organic matter of a volcanic soil under different agronomic management as an indicator of changes in labile organic matter. Agric. Téc. 2002, 62, 284-296.

38. Peichl, M.; Thevathasan, N.V.; Gordon, A.M.; Huss, J.; Abohassan, R. Carbon sequestration potentials in temperate tree-based intercropping systems, southern Ontario, Canada. Agrofor. Syst. 2006, 66, 243-257. [CrossRef]

39. Dube, F.; Thevathasan, N.V.; Stolpe, N.; Espinosa, M.; Zagal, E.; Gordon, A.M. Selected carbon fluxes in Pinus ponderosa-based silvopastoral systems, exotic plantations and natural pastures on volcanic soils in the Chilean Patagonia. Agrofor. Syst. 2013, 87, 525-542. [CrossRef] 
40. Kirsten, M.; Kaaya, A.; Klinger, T.; Feger, K.-H. Stocks of soil organic carbon in forest ecosystems of the eastern Usambara mountains, Tanzania. Catena 2016, 137, 651-659. [CrossRef]

41. Morales-Barquero, L.; Skutsch, M.; Jardel-Peláez, E.J.; Ghilardi, A.; Kleinn, C.; Healey, J.R. Operationalizing the definition of forest degradation for REDD+, with application to Mexico forests. Forests 2014, 5, 1653-1681. [CrossRef]

42. Wen-Jie, W.; Ling, Q.; Yuan-Gang, J.; Dong-Xue, S.; Jing, A.; Hong-Yan, W.; Guan-Yu, Z.; Wei, S.; Xi-Quan, C. Changes in soil organic carbon, nitrogen, $\mathrm{pH}$ and bulk density with the development of larch (Larix gmelinii) plantations in China. Glob. Chang. Biol. 2011, 17, 2657-2676. [CrossRef]

43. Candan, F.; Broquen, P. Aggregate stability and related properties in NW Patagonian Andisols. Geoderma 2009, 154, 42-47. [CrossRef]

44. Dorner, J.; Sandoval, P.; Dec, D. The role of soil structure on the pore functionality of an Ultisol. J. Soil Sci. Plant Nutr. 2010, 10, 495-508. [CrossRef]

45. Shoji, S.; Nanzyo, M.; Dahlgren, R. Volcanic Ash Soils, Genesis, Properties and Utilization; Elsevier: New York, NY, USA, 1993; pp. 1-288.

46. Wäldchen, J.; Schulze, E.D.; Schöning, I.; Schrumpf, M.; Sierra, C. The influence of changes in forest management over the past 200 years on present soil organic carbon stocks. For. Ecol. Manag. 2013, 289, 243-254. [CrossRef]

47. Zagal, E.; Córdova, C. Soil organic matter quality indicators in a cultivated Andisol. Agric. Téc. 2005, 65, 186-197.

48. Dube, F.; Department of Silviculture, Faculty of Forest Sciences, University of Concepción, Concepción, Chile. Carbon loss and degradation indicators in Nothofagus forests of the Andes and Coastal range in Mediterranean Chile. Unpublished data. 2016.

49. Lu, G.; Sakagami, K.; Tanaka, H.; Hamada, R. Role of soil organic matter in stabilization of water-stable aggregates in soils under different types of land uses. Soil Sci. Plant Nutr. 1998, 44, 147-155. [CrossRef]

50. Dube, F.; Department of Silviculture, Faculty of Forest Sciences, University of Concepción, Concepción, Chile. Degradación de bosques de Nothofagus obliqua, su efecto en el suelo y su contribución al cambio climático. Unpublished data. 2016.

51. Sohi, S.P.; Mahieu, N.; Arah, J.R.M.; Powlson, D.S.; Madari, B.; Gaunt, J.L. A procedure for isolating soil organic matter fractions suitable for modeling. Soil Sci. Soc. Am. J. 2001, 65, 1121-1128. [CrossRef]

52. Smith, J.U.; Smith, P.; Monaghan, R.; MacDonald, A.J. When is a measured soil organic matter fraction equivalent to a model pool? Eur. J. Soil Sci. 2002, 53, 405-416. [CrossRef]

53. Smith, P. Monitoring and verification of soil carbon changes under Article 3.4 of the Kyoto Protocol. Soil Use Manag. 2004, 20, 264-270. [CrossRef]

54. Magrin, G.O.; Marengo, J.A.; Boulanger, J.-P.; Buckeridge, M.S.; Castellanos, E.; Poveda, G.; Scarano, F.R.; Vicuña, S. Central and South America. In Climate Change 2014: Impacts, Adaptation, and Vulnerability. Part B: Regional Aspects. Contribution of Working Group II to the Fifth Assessment Report of the Intergovernmental Panel on Climate Change; Barros, V.R., Field, C.B., Dokken, D.J., Mastrandrea, M.D., Mach, K.J., Bilir, T.E., Chatterjee, M., Ebi, K.L., Estrada, Y.O., Genova, R.C., et al., Eds.; Cambridge University Press: Cambridge, UK; New York, NY, USA, 2014; pp. 1499-1566.

(C) 2016 by the authors; licensee MDPI, Basel, Switzerland. This article is an open access article distributed under the terms and conditions of the Creative Commons Attribution (CC-BY) license (http://creativecommons.org/licenses/by/4.0/). 